\title{
Absence of noticeable mercury effects on fish populations in boreal reservoirs despite threefold to sevenfold increases in mercury concentrations
}

\begin{tabular}{|r|l|}
\hline Journal: & Canadian Journal of Fisheries and Aquatic Sciences \\
\hline Manuscript ID & cjfas-2015-0035.R2 \\
\hline Manuscript Type: & Article \\
\hline Date Submitted by the Author: & $25-$ Nov-2015 \\
\hline Complete List of Authors: & $\begin{array}{l}\text { Bilodeau, François; Hydro-Québec, Environnement } \\
\text { Schetagne, Roger; Hydro-Québec, Environnement } \\
\text { Therrien, Jean; WSP, Environnement } \\
\text { Verdon, Richard; Hydro-Quebec, Environment }\end{array}$ \\
\hline Keyword: & $\begin{array}{l}\text { RESERVOIRS < Environment/Habitat, MERCURY < General, GROWTH }< \\
\text { General, RECRUITMENT < General, FISHES < Organisms }\end{array}$ \\
\hline
\end{tabular}




\section{Absence of noticeable mercury effects on fish populations in boreal reservoirs 3 despite threefold to sevenfold increases in mercury concentrations 4}

5 François Bilodeau, Roger Schetagne, Jean Therrien and Richard Verdon 6

7

8

9

10

11

12

13

14

15

16

17

18

19

20

21

22

23

24

25

26

27

28

29

30

\section{Introduction}

32 Mercury, in the organic form of methylmercury, 33 bioaccumulates in fish primarily through dietary uptake (Spry 34 and Wiener 1991; Rodgers 1994; Hall et al. 1997). The level 35 of bioaccumulation is a function of age, species and trophic 36 transfer (Birge et al. 1979; Spry and Wiener 1991). Several 37 studies have addressed the potential effect of mercury in the 38 environment and its impact on fish reproduction (Crump and 39 Trudeau 2009; Weis 2009; Depew et al. 2012). These studies 40 were primarily carried out in the laboratory, in controlled

\begin{abstract}
At the La Grande hydroelectric complex (Québec, Canada), total mercury concentrations were measured in more than 25,000 fish over a 20-year period. Fish population characteristics, such as fishing yield, growth rate, condition factor and recruitment, were also monitored. In reservoirs, total mercury concentrations in all species increased rapidly after impoundment, peaking after 4 to 9 years in nonpiscivorous fish, and after 9 to 11 years in piscivorous species, at levels 3 to 7 times those measured in surrounding natural lakes, then declined gradually and significantly. Despite this increase, most species showed increases in fishing yields (by factors ranging from 2 to 8 ), growth rates and condition factors (for more than a decade). The percentage of small specimens of the main species was generally maintained or increased in the first years after flooding, indicating good recruitment.
\end{abstract}

Résumé: Au complexe hydroélectrique La Grande (Québec, Canada) des analyses de mercure total ont été effectuées sur plus de 25000 poissons sur une période de plus de 20 ans. Certaines caractéristiques populationnelles de poisson ont également été suivies (succès de pêche, croissance, condition et recrutement). En réservoirs, les concentrations de mercure total de toutes les espèces ont augmenté rapidement, atteignant les niveaux maximums 4 à 9 ans après les mises en eau chez les espèces non piscivores et après 9 à 11 ans chez les piscivores, à des niveaux 3 à 7 fois ceux mesurés initialement, puis elles ont diminué graduellement et significativement. Malgré cette hausse, des augmentations ont été observées dans les succès de pêche (facteurs de 2 à 8 ), dans les taux de croissance et dans le facteur de condition (pour plus de 10 ans) pour la majorité des espèces. Le pourcentage de petits spécimens s'est généralement maintenu ou a augmenté les premières années après les mises en eau, indice d'un bon recrutement.

Keywords : mercury, boreal reservoirs, fish populations, recruitment, growth Mots clés : Mercure, réservoirs boréaux, populations de poisson, recrutement, croissance

41 environments and with methylmercury concentrations 42 generally much higher than those occurring in natural 43 environments (e.g. aqueous exposure of $\mu \mathrm{g} \mathrm{L^{-1 }}$ in laboratory 44 vs. $\mathrm{ng} \mathrm{L}^{-1}$ in natural environments), although some were done 45 in the field (Friedmann et al. 2002; Latif et al. 2001; Larose 46 et al. 2008) and some, using concentrations similar to those 47 occurring in natural environments (Friedmann et al. 1996a; 48 Mela et al. 2007).

49 Direct mortality due to methylmercury is observed only 50 at unusually high tissue concentrations $\left(6-20 \mu \mathrm{g} \mathrm{g}^{-1}\right.$ wet 51 weight in muscle) in cases involving extreme, gross pollution

F. Bilodeau, Environment Department, Hydro-Québec Production, Montréal, Québec, H2Z 1A4, Canada, (bilodeau.francois@hydro.qc.ca)

R. Schetagne, Environmental consultant, Mascouche, Québec, J7L 1B8, Canada (r.schetagne@bell.net)

R. Verdon, Environmental consultant, Montréal, Québec, H1K 5C4, Canada (verdonr@videotron.ca)

J. Therrien, WSP Canada Inc. (Environmental Consultants), Québec City, Québec, G2J 1C9, Canada (jean.therrien@wspgroup.com)

Corresponding author: François Bilodeau 
52 (Wiener and Spry 1996). Effects of methylmercury on 53 growth of fish vary greatly in laboratory experiments, from 54 negative to positive correlations to absence of correlation, 55 with a wide range of exposure concentrations (2.4 to $565.6 \mu \mathrm{g} \mathrm{g}^{-1}$ wet weight in carcass-whole fish minus viscera) 57 and fish species (Friedmann et al. 1996a; Hammerschmidt et 58 al. 2002; Sandheinrich and Weiner 2011). Some field 59 studies have found an inverse relationship between mercury 60 concentrations and fish condition factor for a number of 61 species such as walleye (Sander vitreus) and northern pike 62 (Esox lucius) at concentration below or around $1 \mu \mathrm{g} \mathrm{g}^{-1}$ wet 63 weight in muscle (Anderson and Newman 1996; Drevnick 64 et al. 2008; Munn and Short 1997). However, Sandheinrich 65 and Weiner (2011) mention that the relation between 66 mercury exposure and fish condition may be confounded by 67 other co-occurring contaminants or fish age. Effects of 68 mercury on behavior were also observed (in laboratory 69 experiments at very high or field-relevant concentrations), 70 mainly on the response to visual signs of predation threat, 71 schooling behavior, spawning onset and feeding (Scott and 72 Sloman 2004; Weis et al. 2011; Weis and Candelmo 2012).

73 Mercury-related effects on reproduction of fish have 74 been found in a number of laboratory experiments using 75 several reproductive endpoints, at environmentally relevant 76 concentrations, such as below 1 to $2.37 \mu \mathrm{g} \mathrm{g}^{-1}$ (wet weight 77 in muscle) (Drevnick and Sandheinrich 2003). Reproduction 78 effects from field studies were usually inferred from effects 79 on organs (hypothalamus, pituitary, gonads, liver) or their 80 function (gametogenesis, fertilization, reproductive 81 hormones), or on embryonic development (Crump and 82 Trudeau 2009; Weis 2009; Scheuhammer et al. 2012), but 83 no reproduction impairment was directly observed in the 84 wild. In some cases, direct effects are inconclusive despite 85 mercury concentrations above the threshold for biological 86 effects (Scheuhammer et al. 2014; Batchelar et al. 2012, 87 2013).

88 It has been well documented that reservoir impoundment 89 may cause an increase in mercury concentration along the 90 food chain and ultimately in fish (Bodaly and Fudge 1999; 91 Lucotte et al. 1999; Bodaly et al. 2004). The rate of increase 92 in mercury would depend on reservoir characteristics such 93 as annual volume of water, area of flooded land, filling time 94 and organic matter in flooded area (Schetagne and Verdon 95 1999), as well as on water quality characteristics such as $96 \mathrm{pH}$, dissolved sulphate, total organic carbon and temperature 97 (Schetagne and Verdon 1999; Wiener et al. 2006; Drevnick 98 et al. 2007). Depending on these factors, the increase may 99 be significant and may last for more than a decade in fish 100 (Schetagne and Verdon 1999; Bodaly et al. 2007).

101 As part of Phase I of the La Grande hydroelectric 102 complex, built from 1973 to 1985, 5 large reservoirs were 103 impounded, namely Robert-Bourassa, La Grande 3, La 104 Grande 4, Caniapiscau and Opinaca, and 3 generating 105 stations were constructed, namely Robert-Bourassa, La 106 Grande-3 and La Grande-4 (Fig. 1). The generating stations 107 were built along the La Grande Rivière. The reservoirs were 108 impounded from 1978 to 1984 , had mean depths varying 109 from 8.2 to $29.4 \mathrm{~m}$ and annual drawdown varying between
1102.1 and $8.0 \mathrm{~m}$. The cumulative flooded area was $9,675 \mathrm{~km}^{2}$ 111 (Table 1).

112 Monitoring of fish populations focused on three large 113 reservoirs (Robert-Bourassa, Opinaca and Caniapiscau) and 114 was carried out from 1978 to 1999, including lakes in pre-

115 flooding conditions. Mercury monitoring was carried out at 116 all La Grande reservoirs because of potential health risks 117 related to fish consumption and is still ongoing because of 118 new construction phases.

119 The mercury-related effects on growth, condition factor, 120 behavior and reproduction, observed in the studies discussed 121 above, were documented for individual fish but never 122 confirmed at the fish population level, with the exception of 123 a few studies referring to cases of industrial pollution 124 (Scherer et al. 1975; Wiener and Spry 1996; Adams et al. 125 1999). This paper will focus on the three major reservoirs in 126 which fish population parameters (between 1978 and 1999) 127 and mercury levels (between 1978 and 2003) were 128 monitored on a regular basis. The main objective of this 129 paper is to determine whether the post-impoundment 130 increases in fish mercury concentrations, at levels up to 3 to 1317 times those in natural surrounding lakes, were associated 132 with any effects in fish at the population level. The specific 133 objectives are to determine whether reduced fish condition 134 and growth rate shown in individuals in the laboratory, were 135 also observed in large reservoir populations, and also to see 136 if these populations show characteristics that would indicate 137 reproduction impairments as was observed in laboratory 138 fish.

139

\section{Material and methods}

\section{Data collection}

142 The data presented in this paper come from two 143 sampling programs: the fish populations monitoring and the 144 mercury in fish monitoring.

\section{Fish populations monitoring}

146 In the western sector of the La Grande complex (Robert147 Bourassa and Opinaca reservoirs, and Eastmain-Opinaca-La 148 Grande diversion, see Fig. 1), fish populations were 149 sampled annually from 1978 or 1979 to 1984, and every 150 four years afterward, from 1988 to 1996. In the eastern 151 sector (Caniapiscau reservoir), sampling was carried out 152 every year from 1980 to 1982 , then every four years from 1531987 to 1999 . Sampling was done four to five times every 154 year from June to October until 1995, when the fishing 155 protocol was optimized to concentrate the sampling effort in 156 July and August (Deslandes and Fortin 1994). All sampling 157 was done with four multifilament gillnets $45.7 \mathrm{~m}$ in length 158 and $2.4 \mathrm{~m}$ in height, set in pairs, a net of uniform 7.6 or $15910.2-\mathrm{cm}$ stretched mesh attached to an experimental gillnet 160 (stretched mesh ranging from 2.5 to $10.2 \mathrm{~cm}$ ). Each set of 161 nets was set perpendicular to and near the shore. Each 162 sampling period lasted $24 \mathrm{~h}$ until 1994, and was then 163 increased to $48 \mathrm{~h}$ until 1999 . The nets were visited every 164 day, for a global fishing effort per station of 4 to 5 days. A 165 total of 16 stations were sampled: 5 in Robert-Bourassa 
166 reservoir, 4 in Opinaca reservoir, 4 in Caniapiscau reservoir 167 and 3 in natural reference lakes.

\section{Mercury in fish monitoring}

169 Mercury in fish monitoring was carried out at all La 170 Grande reservoirs because of potential health risks related to 171 fish consumption. For the Robert-Bourassa, Opinaca and 172 Caniapiscau reservoirs, monitoring was done at the stations 173 sampled for the fish populations program. For the other 174 reservoirs, mercury was monitored at 3 to 5 sampling 175 stations per reservoir. In the western sector, monitoring was 176 carried out in 1978 (pre-impoundment) then every 2 years 177 from 1982 to 2000. In the eastern sector, monitoring was 178 carried out in 1980 (pre-impoundment) then every 2 years 179 from 1987 to 1999 . Mercury monitoring is still ongoing 180 because of new construction phases (Phase II from 1987 to 181 1996, Eastmain 1 reservoir from 2002 to 2006, and 182 Eastmain 1A and Rupert diversion from 2007 to 2012).

183 For the years were both mercury and fish populations 184 were monitored, fish for mercury analysis were taken from 185 the fish population sampling, whereas during the years were 186 only mercury was monitored, fish were collected with 187 experimental gillnets (stretched mesh ranging from 2.5 to $18810.2 \mathrm{~cm}$ ) as well as with multifilament nets of uniform 2.5, 1897.6 or $10.2-\mathrm{cm}$ stretched mesh.

190 A nearby reference lake was associated with each of the 1913 monitored reservoirs and were also sampled at the same 192 times (Detcheverry, Rond-de-Poêle and Hazeur lakes shown 193 in Fig. 1). These lakes had the same fish community as the 194 reservoirs and, having a surface area varying from 6 to 20 $195 \mathrm{~km}^{2}$, were large enough to support the same fishing effort 196 carried out in the reservoirs without impairing populations. 197 Water chemistry in those lakes were very similar to the 198 lakes and rivers flooded by the impoundment of the 199 reservoirs : average $\mathrm{pH}$ varied from 6.5 to 7.1 in lakes 200 compared to 6.1 to 6.6 in reservoirs; conductivity was very 201 low and ranged from 9 to $36 \mu \mathrm{S} \mathrm{cm}^{-1}$ in lakes and 9 to $20219 \mu \mathrm{S} \mathrm{cm}^{-1}$ in reservoirs, total phosphorous values were also 203 very low, ranging from 5 to $9 \mu \mathrm{g} \mathrm{L}^{-1}$ in lakes and from 5 to $20410 \mu \mathrm{g} \mathrm{L}^{-1}$ in reservoirs; as was chloropyll a, ranging from 2050.9 to $1.9 \mu \mathrm{g} \mathrm{L}^{-1}$ in lakes and from 1.4 to $1.9 \mu \mathrm{g} \mathrm{L}^{-1}$ in 206 reservoirs. In addition, a total of 31 natural lakes in the La 207 Grande complex region, were also sampled to determine 208 background mercury levels in fish.

209 For both, fish populations and mercury in fish 210 monitoring, the fish caught were identified, counted, 211 measured and weighed, and sex and maturity were 212 determined. Bone structures were also taken for age 213 determination on a subsample of fish. Samples of $50 \mathrm{~g}$ of 214 muscle were taken for mercury analysis on a subsample of 215 fish (usually 30 fish per species, per station, per year, well 216 distributed according to length). For mercury analysis, the 217 most abundant or consumed fish species were selected: two 218 non-piscivorous species, namely lake whitefish and 219 longnose sucker (Catostomus catostomus), and three 220 piscivorous species, namely northern pike, walleye and lake 221 trout.

\section{Data analysis}

224 Because filling time extended over more than one year 225 in some reservoirs, the first year of impoundment is 226 considered as year 0 for all of them, which is different from 227 the baseline. For the western sector of the La Grande 228 Complex (Robert-Bourassa and Opinaca reservoirs), pre229 impoundment data from future reservoir stations were 230 pooled for 1977 and 1978 to increase the sample size.

231

\section{Fish density}

233 Catch per unit of effort (CPUE) was used as an indicator 234 of fish density. This is adequate for temporal comparison 235 when stations, period and gears are the same (Ricker 1980), 236 which is the case in the present study. For a given water 237 body (reference lake or reservoir) and year, catches of all 238 sampling nets were averaged ( $\mathrm{N}$ of 8 to 120 depending on 239 reservoir for each year) and expressed as fishing yields in 240 number of fish per net-day (CPUE). To obtain rigorously 241 comparable data from 1978 to 1999 , only data available for 242 the months of July and August were used for the CPUE 243 calculations. For the various species, variance analysis 244 (ANOVAs) and Tukey's HSD tests $(\alpha<0.05)$ were used to 245 compare annual means in CPUE between pre-impoundment 246 and post-impoundment years, and ANOVAs and Kruskall247 Wallis tests $(\alpha<0.05)$ were used for the comparisons 248 between reservoir and natural lake every year.

249

250 Growth, condition and small-size fish 251 proportions

252 Age determination was used to generate growth curves 253 with the von Bertalanffy equation (Ricker 1980):

254 Length $=L \max \left(1-e^{(-k(t-t 0)}\right)$

255 Were $L \max =$ maximal length of the species, $256 \mathrm{k}=\mathrm{a}$ constant, $\mathrm{t}=$ age of fish (year), and $\mathrm{t} 0=\mathrm{age}$ at 257 length $=0$.

258 Age was determined using the cleithrum for northern 259 pike (Massé 1979; Casselman 1979), the otoliths and 260 operculum for walleye (Pépin and Lévesque 1985), the 261 otoliths for lake whitefish and lake trout (Power 1978; 262 Morin et al. 1982; Dubois and Lagueux 1978). The first 263 pectoral fin ray was used for longnose sucker (Beamish 264 1973; Verdon and Magnin 1977). Age determination is 265 available from 1977 to 2000 , using the mercury monitoring 266 data in this last year. Statistical comparison $(\alpha<0.05)$ was 267 performed with length using ANOVAs and SNK or 268 Kruskall-Wallis tests $(\alpha<0.05)$ at a given age between years.

269 The Fulton condition factor (K) was determined by the 270 following equation (Ricker 1980):

$271 \quad K=\frac{\text { Weight }(g) X 10^{5}}{\operatorname{Length}(\mathrm{mm})}$

272 Changes in the condition factor in modified and 273 reference environments were compared using all the data 274 available (catches from all months and monitoring) and 275 using individuals of the most abundant length classes for 276 each species, to eliminate effects of interannual variations in 
277 length distribution. The use of all data available is valuable 278 because there is no significant differences between the 279 condition factor values obtained with only July and August 280 data compared to all months sampled (Deslandes and Fortin, 281 1994), and the variances were lower, allowing an easier 282 temporal comparison between years. Length classes used 283 were 300 to $500 \mathrm{~mm}$ for lake whitefish and longnose sucker, 284400 to $600 \mathrm{~mm}$ for walleye, 600 to $800 \mathrm{~mm}$ for lake trout 285 and 500 to $700 \mathrm{~mm}$ for northern pike. For the various 286 species, ANOVAs and SNK or Kruskall-Wallis tests $287(\alpha<0.05)$ were used to compare annual means in condition 288 factors (minimum of five fish) for a given environment 289 between pre-impoundment and post-impoundment years. 290 Because the nets were not set in the same pair assemblage 291 for mercury monitoring as for fish population monitoring, 292 only the data collected from fish caught by the fish 293 population sampling protocol were used to calculated 294 CPUE, growth, and small-size fish proportions. 295 Exceptionally, because of the selection of fish subsamples 296 according to length classes and considering the frequent use 297 of the same fishing gear for fish population and mercury 298 monitoring, the condition factor was also determined for 299 fish gathered after 1996 from complementary studies (1998, $3002000)$ or from mercury monitoring $(1986,1989,1990,1994$, 301 1997, 2000, 2003).

302 Trends in recruitment were inferred from the percentage 303 of small specimens in yearly length-composition data $304(<250 \mathrm{~mm}$ for lake whitefish, longnose sucker and walleye, $305<350 \mathrm{~mm}$ for northern pike, $<600 \mathrm{~mm}$ for lake trout). These 306 length limits represents approximately the tenth centiles of 307 the lengths of each species in all natural environment (all 308 surveys together). Only the fish population monitoring data 309 (1978-1999) were used for this aspect. Comparisons 310 between pre-impoundment and post-impoundment years and 311 between reservoir and natural lake each year were done with 312 binomial or Poisson Law ( $\%<5 \%$ or $>95 \%$ ) hypothesis tests $313(\alpha<0.05)$, in which $0.001 \%$ replaced zero values.

314

\section{Mercury analysis}

316 The determination of total mercury $\left(\mu \mathrm{gg}^{-1}\right.$ of wet 317 weight) was done using Cold Vapor Atomic Absorption 318 Spectrophotometry (CVAAS), as recommended by 319 Environment Canada (1979). All analyses were performed 320 by independent laboratories accredited by the Québec 321 government to analyze total mercury. The quality control 322 included: method blanks, standard additions, $15 \%$ of fish 323 samples measured in triplicate, certified standards from the 324 National Research Council of Canada. Further quality 325 control was performed on blind triplicates sent to the 326 laboratories without their knowledge (taken from $10 \%$ of all 327 fish analyzed for mercury).

328 The detection limit varied from 0.01 to $0.05 \mu \mathrm{g} \mathrm{g}^{-1}$ (wet 329 weight) from 1977 to 2003 . Because the detection limit has 330 been lower since 1997 than in earlier years (0.01 to $3310.02 \mu \mathrm{g} \mathrm{g}^{-1}$ vs. $0.05 \mu \mathrm{g} \mathrm{g}^{-1}$ ), a number of values below $3320.05 \mu \mathrm{g} \mathrm{g}^{-1}$ were obtained. Since this situation may skew the 333 results relative to earlier years, the data below $0.05 \mu \mathrm{g} \mathrm{g}^{-1}$ 334 measured since 1997 was automatically considered to be at
335 this threshold to make it comparable to the data from 336 previous years.

337 The evaluation of analytical performance (relative to 338 repeatability), which was determined using the different 339 control procedures, helped establish the yearly average 340 coefficient of variation (standard deviation/mean x 100), 341 which ranged from $3.4 \%$ to $8.5 \%$ from 1986 to 2003 (mean 342 of $5.8 \%$ ). In regard to replicability, yearly average 343 coefficients of variation for accuracy ranging from $3.9 \%$ to $3447.6 \%$ were obtained for all samples from 1986 to 2003 (with 345 an overall mean of $5.7 \%$ ). For concentrations lower than $3460.30 \mu \mathrm{g} \mathrm{g}^{-1}$, the yearly coefficient of variation for accuracy 347 varied from $3.4 \%$ to $5.6 \%$ from 1989 to 2003 (overall mean 348 of $4.7 \%$ ). Average yearly coefficients of variation for the 349 blind triplicate samples varied from $4.1 \%$ to $7.1 \%$, from 3501990 to 2003, with an overall mean of 5.9\%.

351 All mercury data presented in this paper are reported as $352 \mu \mathrm{g} \mathrm{g}^{-1}$ of total mercury (wet weight) for muscle samples. 353 Although the monitoring done was on total mercury and 354 many laboratory experiments on fish use methylmercury, 355 previous studies have well demonstrated that total mercury 356 in fish is a good surrogate for methymercury, as the 357 proportion of methylmercury was found to vary from $80 \%$ 358 to $100 \%$ depending on fish species (Bloom 1992; Watras et 359 al. 1994; Lasorsa and Allen-Gil 1995). Statistical analysis $360(\alpha<0.05)$ of temporal and spatial trends was carried out 361 using polynomial regression analysis with indicator 362 variables (Tremblay et al. 1998). Interannual and spatial 363 comparisons were made using a standard length, 364 corresponding to average lengths in the catches, namely 400 $365 \mathrm{~mm}$ for lake whitefish, longnose sucker and walleye, 700 $366 \mathrm{~mm}$ for northern pike and $600 \mathrm{~mm}$ for lake trout, which 367 correspond, for all species, to lengths at which all 368 individuals were mature.

369 The "background condition" was determined with fish 370 mercury data coming from a total of 31 unaffected natural 371 lakes of the La Grande complex region (respectively 21 and 37210 from the western and eastern sectors), including pre373 flood data from 7 lakes that were flooded during the 374 impoundment of Robert-Bourassa (2 lakes), Opinaca (1 375 lake) and Caniapiscau reservoir (4 lakes). Table 2 shows for 376 each species and each sector, the number of natural lakes 377 sampled, the number fish analyzed, the range of mean 378 mercury levels observed at the standard lengths, and the 379 overall mean mercury levels obtained by pooling the data 380 from all natural lakes. The ranges of mean levels at standard 381 lengths obtained for natural lakes of each sector are 382 presented in figures 2 and 3.

383

\section{Results}

\section{Mercury in fish of natural lakes}

386 Fish total mercury levels vary greatly from one lake to 387 another, as mean concentrations at standard lengths for a 388 given species may vary by factors of up to 4 between 389 neighboring lakes (Table 2). For example, in the western 390 sector of the La Grande complex region, 400-mm lake 391 whitefish from 21 natural lakes show an overall mean 
392 mercury concentration of $0.11 \mu \mathrm{g} \mathrm{g}^{-1}$, but mean levels range 393 from 0.05 to $0.20 \mu \mathrm{g} \mathrm{g}^{-1}$ from one lake to another. A 394 corresponding range of 0.12 to $0.22 \mu \mathrm{g} \mathrm{g}^{-1}$, with an overall 395 average of $0.12 \mu \mathrm{g} \mathrm{g}^{-1}$, was obtained for $400-\mathrm{mm}$ longnose 396 sucker. In the same sector, mean mercury levels for $700-\mathrm{mm}$ 397 northern pike and 400 -mm walleye range respectively from 3980.30 to $0.93 \mu \mathrm{g} \mathrm{g}^{-1}$ and from 0.30 to $1.02 \mu \mathrm{g} \mathrm{g}^{-1}$, with overall 399 mean levels of respectively 0.60 and $0.59 \mu \mathrm{g} \mathrm{g}^{-1}$. In the 400 eastern sector, mean mercury levels in $600 \mathrm{~mm}$ lake trout 401 sampled from 10 natural lakes range from 0.52 to $4021.11 \mu \mathrm{g} \mathrm{g}^{-1}$, with an overall mean of $0.72 \mu \mathrm{g} \mathrm{g}^{-1}$.

403 Mercury levels in fish of natural lakes, monitored 404 regularly from 1984 to 2003, show no increasing or 405 decreasing time trend, with very little year to year variations 406 (Fig. 2), compared to the great increases observed in 407 reservoirs.

408

\section{Mercury in fish of reservoirs}

410 Following impoundment, significant $(\alpha<0.05)$ increases 411 were measured in total mercury concentrations in the 412 muscle of all fish species caught in the three monitored 413 reservoirs. Non-piscivorous species showed increases 414 varying by factors ranging from 3 to 7 depending on species 415 and reservoir (Fig. 3). Mercury levels in 400-mm lake 416 whitefish increased from an overall mean of $0.11 \mu \mathrm{g} \mathrm{g}^{-1}$ in 417 background conditions to a maximum of $0.53 \mu \mathrm{g} \mathrm{g}^{-1}$ in 418 Robert-Bourassa reservoir after 5 years and to $0.46 \mu \mathrm{g} \mathrm{g}^{-1}$ in 419 Opinaca reservoir after 6 years, while in Caniapiscau 420 reservoir it increased from an overall mean in natural lakes 421 of $0.16 \mu \mathrm{g} \mathrm{g}^{-1}$ to $0.47 \mu \mathrm{g} \mathrm{g}^{-1}$ after 9 years (Table 3). In $400-$ $422 \mathrm{~mm}$ longnose sucker, mercury concentrations increased 423 from an overall mean of $0.12 \mu \mathrm{g} \mathrm{g}^{-1}$ in natural lakes to a 424 maximum of $0.63 \mu \mathrm{g} \mathrm{g}^{-1}$ in Robert-Bourassa reservoir (after 4257 years) and from 0.12 to $0.72 \mu \mathrm{g} \mathrm{g}^{-1}$ in Opinaca reservoir 426 (after 4 years). In Caniapiscau reservoir it increased from an 427 overall mean of $0.13 \mu \mathrm{g} \mathrm{g}^{-1}$ to $0.52 \mu \mathrm{g} \mathrm{g}^{-1}$ after 9 years 428 (Table 4).

429 Piscivorous species showed similar increase factors, 430 varying from 3 to 6 (Fig. 3). In 700-mm northern pike, total 431 mercury levels increased from an overall mean of $4320.60 \mu \mathrm{g} \mathrm{g}^{-1}$ in background conditions to a maximum of $4333.34 \mu \mathrm{g} \mathrm{g}^{-1}$ in Robert-Bourassa reservoir (after 11 years) and 434 to $2.77 \mu \mathrm{g} \mathrm{g}^{-1}$ in Opinaca reservoir (after 10 years) 435 (Table 5). In Caniapiscau reservoir, the corresponding 436 concentrations increased from an overall mean of $4370.59 \mu \mathrm{g} \mathrm{g}^{-1}$ to $1.86 \mu \mathrm{g} \mathrm{g}^{-1}$ after 11 years. For walleye $438400 \mathrm{~mm}$ in length, mercury levels increased from $4390.59 \mu \mathrm{g} \mathrm{g}^{-1}$ in background conditions to a maximum of $4402.82 \mu \mathrm{g} \mathrm{g}^{-1}$ in Robert-Bourassa reservoir (after 9 years) and 441 from 0.59 to $2.07 \mu \mathrm{g} \mathrm{g}^{-1}$ in Opinaca reservoir (after 44210 years) (Table 6). In 600-mm lake trout, the mean 443 concentration in natural lakes was $0.72 \mu \mathrm{g} \mathrm{g}^{-1}$ and reached a 444 maximum of $1.85 \mu \mathrm{g} \mathrm{g}^{-1}$ in Caniapiscau reservoir, 9 years 445 after impoundment (Table 7).

446 Mercury levels then gradually and significantly 447 decreased in all species, except lake trout of Caniapiscau 448 reservoir, reaching or almost reaching the range of 449 background levels in lake whitefish and longnose sucker
450 after 17 to 21 years of impoundment. (Fig. 3 and tables 3 451 and 4). In 1999 and 2000, the last sampling year for which 452 both mercury levels and fish population characteristics are 453 both available, mean mercury levels in standard-length 454 northern pike and walleye corresponded to the following 455 decreases compared to peak concentrations: 19 to $45 \%$ for 456 northern pike and 50 to $63 \%$ for walleye depending on the 457 reservoir (Fig. 3 and tables 5 and 6).

458 Bodaly et al. (2007) showed that increases in fish 459 mercury levels are temporary in Boreal reservoirs and that 460 complete returns to the range of background levels should 461 be expected 10 years to 30 years after impoundment, 462 depending on species and standard-lengths used. 463 Subsequent unpublished mercury data from 2002 to 2012 464 for the La Grande complex reservoirs confirmed this time 465 frame for all species and reservoirs except for northern pike 466 of the Robert-Bourassa reservoir (Schetagne and Therrien, 467 2013).

468

\section{Fish density}

470 In some cases, such as lake whitefish in Caniapiscau 471 reservoir and walleye in Robert-Bourassa and Opinaca 472 reservoirs, a significant decrease in fishing yields was 473 observed for the first few years following impoundment. 474 Then, during the periods when fish mercury levels were 475 increasing, fishing yields also showed statistically 476 significant $(\alpha<0.05)$ increases, compared to pre477 impoundment values, in all three reservoirs for most 478 species, the exceptions being for longnose sucker in 479 Opinaca reservoir and lake trout in Caniapiscau reservoir 480 (Tables 3-7).

481 Lake whitefish maximum mercury levels were 482 associated with maximum CPUE in the three monitored 483 reservoirs, in 1984 in Robert-Bourassa and Opinaca 484 reservoirs (the 1986 mercury value in Opinaca, having the 485 same letter in table 3 as the 1984 value, is not significantly 486 different from the 1984 value) and, in 1991 in Caniapiscau 487 reservoir. More specifically, lake whitefish CPUE increased $488(\alpha<0.05)$ by a factor ranging from 1.4 to 3.4 in the three 489 reservoirs. (peak CPUE compared to pre-impoundment 490 values). For all reservoirs, lake whitefish CPUE remained, 491 after peak mercury levels, generally comparable to or 492 greater than those obtained before impoundment or in the 493 natural reference lakes.

494 Longnose sucker CPUE in the three reservoirs also 495 typically remained comparable $(\alpha<0.05)$ to those obtained 496 for reference lakes (Table 4), although the post497 impoundment increase was less pronounced and more 498 variable. Indeed, longnose sucker CPUE comparable to 499 reference lake values, were associated with high or near 500 peak mercury levels (such as $0.61 \mu \mathrm{g} \mathrm{g}^{-1}$ in 1984 in Robert501 Bourassa reservoir, and $0.50 \mu \mathrm{g} \mathrm{g}^{-1}$ in 1992 in Opinaca 502 reservoir and $0.52 \mu \mathrm{g} \mathrm{g}^{-1}$ in Caniapiscau reservoir). For this 503 species, CPUE increase factors ranged from 1.7 to 2.0. After 504 an initial increase of longnose sucker density in Robert505 Bourassa reservoir, the subsequent decrease led, for a 506 number of years, to fishing yields below initial values or 507 surrounding natural lake values. 
508 Northern pike CPUE increased markedly $(\alpha<0.05)$ in 509 all reservoirs (by factors ranging from 3.8 to 9.4), and 510 values greater than before impoundment and reference lake 511 values were often obtained for the years where maximum or 512 near maximum mercury levels were measured (Table 5).

513 In Robert-Bourassa reservoir, after an initial significant 514 decrease in CPUE values during the first few years after 515 impoundment, the year-to-year walleye CPUE fluctuates in 516 the same manner as in the reference lake. CPUEs not 517 significantly different $(\alpha<0.05)$ from the pre-impoundment 518 value were obtained from 1982 to 1988 (2.0 to 3.4) and 519 were associated with maximum or near maximum mercury 520 levels $\left(2.03 \mu \mathrm{g} \mathrm{g}^{-1}\right.$ to $\left.2.82 \mu \mathrm{g} \mathrm{g}^{-1}\right)$. Moreover, a CPUE not 521 significantly different $(\alpha<0.05)$ from the pre-impoundment 522 value but significantly greater than in the reference lake $523(\alpha<0.05)$ was obtained in the last year of monitoring (1996), 524 after the period of higher mercury levels (Table 6). In 525 Opinaca reservoir, a gradual significant reduction in walleye 526 CPUE was observed before the maximum increase in 527 mercury levels, but in 1992, shortly after the maximum 528 mercury level of $2.07 \mu \mathrm{g} \mathrm{g}^{-1}$, a CPUE of 3.4 , not 529 significantly different $(\alpha<0.05)$ from the pre-impoundment 530 value, was obtained.

531 Lake trout is an exception, as its CPUE in Caniapiscau 532 reservoir gradually declined $(\alpha<0.05)$ after impoundment 533 (from an average of 2.7 to 0.6 ), while mercury levels 534 gradually increased (Table 7).

535

\section{Fish growth}

537 In the three reservoirs, growth rates in all the main 538 species were markedly higher after impoundment (Fig. 4 to 5396 ). These figures show the growth rates (fish length as a 540 function of fish age) obtained for the different fish species, 541 for years before, during and after (last year of monitoring) 542 peak mercury levels. Lake whitefish growth rates were 543 consistently higher than pre-impoundment rates, up to 16 544 and 21 years after impoundment in Opinaca and Robert545 Bourassa reservoirs and were also higher 7 years after 546 impoundment in Caniapiscau reservoir. For example, during 547 peak mercury levels $\left(0.46 \mu \mathrm{g} \mathrm{g}^{-1}\right.$ in 1986) in Opinaca 548 reservoir, lake whitefish reached $400 \mathrm{~mm}$ in length at age 6 549 as opposed to age 11 in pre-impoundment conditions (at $\left.5500.11 \mu \mathrm{g} \mathrm{g}^{-1}\right)$.

551 Longnose sucker growth rates were consistently higher 552 than pre-impoundment rates, up to 19 and 21 years after 553 impoundment in Caniapiscau and Robert-Bourassa 554 reservoirs. For example, during near peak mercury levels $555\left(0.61 \mu \mathrm{g} \mathrm{g}^{-1}\right.$ in 1984) in Robert-Bourassa reservoir, longnose 556 sucker reached $400 \mathrm{~mm}$ in length at age 8 as opposed to age

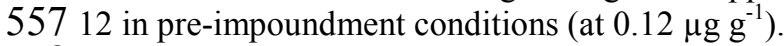

558 Northern pike growth rates were higher or similar to 559 pre-impoundment rates, up to 16 and 21 years after 560 impoundment in Opinaca and Robert-Bourassa reservoirs. 561 For example, during near maximum mercury levels in $700-$ $562 \mathrm{~mm}$ fish (2.47 $\mathrm{\mu g} \mathrm{g}^{-1}$ in 1994) in Opinaca reservoir, northern 563 pike reached $800 \mathrm{~mm}$ in length at age 8 that year, as 564 opposed to age 14 in pre-impoundment conditions (Fig. 5).
565 Mean mercury levels in $800-\mathrm{mm}$ northern pike were then $5663.24 \mu \mathrm{g} \mathrm{g}^{-1}$, as opposed to $0.79 \mu \mathrm{g} \mathrm{g}^{-1}$ in natural conditions.

567 In Robert-Bourassa and Opinaca reservoirs, walleye 568 growth rates were consistently higher than pre569 impoundment rates, up to 21 years after impoundment (Fig. 5704 and 5), before and after peak mercury levels. For example, 571 in Opinaca reservoir in 1994, walleye reached $400 \mathrm{~mm}$ in 572 length at age 8 , as opposed to age 11 in pre-impoundment 573 conditions.

574 In Caniapiscau reservoir, lake trout growth rates were 575 higher than pre-impoundment rates, 9 years (1989) and 19 576 years (1999) after impoundment, which corresponds to 577 before and after peak mercury levels (1991). In 1999, lake 578 trout reach $600 \mathrm{~mm}$ in length at age 4 compared to age 7 in 579 pre-impoundment conditions.

580 The number of fish available for a given year, for each 581 specific age class (for each species, reservoir, and reference 582 lake) is often not sufficient to perform statistical 583 comparisons between years. Nevertheless, significant 584 increases in the mean length at a given age $(\alpha<0.05)$, 585 compared to natural conditions, were found at young ages 586 for almost all the species in all reservoirs. For example, 5, 6 587 and 7 year-old lake whitefish were significantly longer in 588 Robert-Bourassa reservoir in 1982 than in pre-impoundment 589 conditions; the same holds true for 7 year-old lake whitefish 590 in Opinaca reservoir in 1986 and 1996, as well as for 6 year591 old lake whitefish in Caniapiscau reservoir in 1987. For 592 longnose sucker, 9 and 10 year-old fish were significantly 593 longer in Robert-Bourassa reservoir in 1982, 1984 and 2000 594 than in natural conditions, as were 9 year old specimens in 5951987 in Caniapiscau reservoir. For northern pike, 6 year596 old specimens were significantly longer in 1982 and 1992 in 597 Robert-Bourassa reservoir, compared to background 598 conditions, as well as 7 and 8 year-old specimens in 1992 in 599 the same reservoir. For walleye, 5 year old fish were 600 significantly longer in Robert-Bourassa reservoir, in 1996, 601 as well as 6,9 and 12 year-olds in 2000; the same holds true 602 for 7,8 and 14 year-olds in 1984. For lake trout, 10 year603 old specimens were significantly longer than pre604 impoundment in Caniapiscau reservoir in 1989.

605

\section{Fish condition}

607 The fish condition factor $\mathrm{K}$ increased significantly $608(\alpha<0.05)$ after impoundment, in all species and reservoirs 609 (Fig. 3 and Tables 3 to 7), except for northern pike of 610 Caniapiscau reservoir. For the non-piscivorous lake 611 whitefish and longnose sucker (Fig. 3a and b and Tables 3 612 and 4), condition factor patterns were fairly well 613 synchronized with mercury concentration patterns shortly 614 after impoundment. Indeed, for lake whitefish increased 615 values of both mercury and fish condition were observed a 616 few years after impoundment, with $\mathrm{K}$ values higher than 617 pre-impoundment associated with high values of mercury 618 from 1981 to 1986 in Robert-Bourassa reservoir, in 1984 in 619 Opinaca, and from 1987 to 1989 in Caniapiscau (Fig. 3a and 620 Table 3). Lake whitefish condition often remained 621 significantly higher than pre-impoundment values after peak 622 mercury values, such as in 1992, 1996, 1998 and 2000 in 
623 Robert-Bourassa reservoir, in 2000 in Opinaca, and in 1993 624 and 1995 in Caniapiscau. Longnose sucker condition also 625 increased significantly during increasing mercury 626 concentrations the first few years after impoundment of the 627 three reservoirs (Fig. $3 \mathrm{~b}$ and Table 4). Significantly higher 628 condition factors $(\alpha<0.05)$, compared to pre-impoundment 629 values, were observed with significantly higher mercury 630 values $(\alpha<0.05)$, in 1982, 1984 and 1988 in Robert-Bourassa 631 reservoir, in 1984 and 1986 in Opinaca, and in 1987, 1989, 6321993 and 1995 in Caniapiscau. Subsequently, longnose 633 sucker condition often remained significantly higher than 634 pre-impoundment after peak mercury values, such as in 6351992,1996 and 2000 in Robert-Bourassa reservoir, in 2000 636 in Opinaca, and in 1999 and 2003 in Caniapiscau.

637 The piscivorous northern-pike condition factor shows a 638 different pattern in Robert-Bourassa and Opinaca reservoirs 639 (Fig. 3c and Table 5). The initial significant increases $640(\alpha<0.05)$ in condition factor are not synchronized with the 641 increases in mercury levels, as peak condition factors (in 6421981 in Robert-Bourassa reservoir and in 1982 in Opinaca 643 reservoir) are observed well before peak mercury levels 644 (from 1988 to 1992 in Robert-Bourassa and from 1990 to 6451994 in Opinaca). However, northern pike condition factors 646 remained higher than $(\alpha<0.05)$ or comparable to pre647 impoundment or reference lake condition values during and 648 after peak mercury levels, in both of these reservoirs. The 649 only exception was in 1992 in Opinaca reservoir when the 650 condition factor was similar to pre-impoundment but 651 significantly lower than in the reference lake where the 652 highest value in 14 years was obtained.

653 In Caniapiscau reservoir, a colder water body, northern 654 pike condition factors did not show the initial post655 impoundment increase, but remained within the range of 656 condition values observed either before impoundment or in 657 the reference lake (Fig. $3 \mathrm{c}$ and Table 5).

658 As was the case for the non-piscivorous lake whitefish 659 and longnose sucker, the piscivorous walleye and lake trout 660 condition factors pattern of change are fairly well 661 synchronized with mercury concentration patterns (Fig. 2d 662 and 2e and Tables 6 and 7). In Robert-Bourassa and 663 Opinaca reservoirs, significant increases in walleye 664 condition are observed during the period of significant 665 increases in mercury levels (from 1981 to 1984). 666 Subsequently, walleye condition factors, in both these 667 reservoirs, remain significantly higher than pre668 impoundment values during and after peak (or near peak) 669 mercury levels, from 1986 to 1998 in Robert-Bourassa, and 670 from 1986 to 2000 in Opinaca reservoirs.

671 For lake trout in Caniapiscau reservoir, the pattern of 672 change of the condition factor closely follows the mercury 673 concentration pattern, with higher condition values 674 associated with higher mercury values, with the exception of 675 the 1991 condition values which are low in both the 676 reservoir and reference lake (Fig. 2e and Table 7). Condition 677 factors remain noticeably higher $(\alpha<0.05)$ than pre678 impoundment or reference lake values during and after the 679 peak (or near peak), from 1993 to 2003.

680

\section{Fish recruitment}

682 Recruitment can be evaluated by the proportion of small 683 specimens of the main species in the three reservoirs. 684 Tables 3 to 7 show the proportion of small specimens 685 calculated before and after impoundment of the three 686 monitored reservoirs, as well as for the unaffected reference 687 lakes. It does not show a relationship between mercury 688 levels and fish recruitment at the population level, as the \% 689 of small specimens did not systematically show the same 690 pattern of change as mercury.

691 Lake whitefish showed different recruitment patterns, 692 depending on the reservoir, despite similar mercury patterns 693 in all reservoirs (Table 3). In Robert-Bourassa reservoir, 694 the \% of small specimens of lake whitefish was 695 systematically and significantly lower $(\alpha<0.5)$, compared to 696 the pre-impoundment data (1977-78), from the third year of 697 flooding (1981) until the last year of fish population 698 monitoring (1996). This decrease may however not be 699 attributed to mercury levels, as the \% of small lake whitefish 700 was also systematically lower in the reference lake 701 (compared to 1977-78). Indeed, no small specimens were 702 captured in this lake from 1979 to 1996 , while mercury 703 levels remained stable (table 3). These fluctuations may 704 probably be attributed to sampling alea as the lake whitefish 705 yields (CPUE) increased from 1983 to 1988, and then 706 remained equivalent to pre-impoundment values despite 707 lower percentages of small specimens. In Opinaca 708 reservoir, the $\%$ of small lake whitefish increased 709 significantly two years after impoundment (1981) and then 710 remained not significantly different from pre-impoundment 711 values from 1982 to 1996, thus during and after peak 712 mercury levels (from 1984 to 1992), with the exception of 713 the 1983 value, which was significantly lower than pre714 impoundment. In Caniapiscau reservoir, after a significant 715 decrease in the \% of small lake whitefish 5 years after 716 flooding (1987), values significantly higher than pre717 impoundment where obtained from 1991 until 1999, thus 718 during and after peak mercury levels (1991).

719 After-impoundment, longnose sucker recruitment 720 patterns were less variable than for lake whitefish in the 3 721 monitored reservoirs (table 4). After an initial significant 722 decrease during the filling of Robert-Bourassa reservoir 723 (1979), the \% of small longnose sucker remained not 724 significantly different from pre-impoundment values from 7251980 to 1996 , thus during and after peak mercury levels 726 (1984 to 1987). The same pattern was observed in 727 Caniapiscau reservoir where, after an initial significant 728 decrease during filling (1982), the \% of small longnose 729 sucker remained not significantly different from pre730 impoundment values from 1987 to 1999 , thus during and 731 after peak mercury levels (1989 to 1993). In Opinaca 732 reservoir, the \% of small longnose sucker always remained 733 not significantly different from pre-impoundment values, 734 thus, before and after peak mercury levels which occurred in 7351984 and 1986 (table 4).

736 Although small northern pike were seldom caught in 737 the reference lakes during the fish population monitoring 738 period (table 5), sufficient specimens were caught in the 
739 reservoirs to show that recruitment was apparently not 740 affected by mercury. In Robert-Bourassa reservoir, a 741 significant increase in the \% of small northern pike was 742 observed after filling, from 1980 to 1982 , followed by a 743 significant decrease in 1984, after which values remained 744 not significantly different from pre-impoundment values 745 (from 1988 to the last year of monitoring in 1996), thus 746 during and after peak mercury levels occurring from 1988 to 747 1992). The same pattern was observed in Opinaca 748 reservoir where, a significant increase in the \% of small 749 northern pike was observed after filling (in 1981 and 1982), 750 followed by a significant decrease in 1984, after which 751 values remained not significantly different from pre752 impoundment values (from 1988 to the last year of 753 monitoring in 1996), thus during and after peak mercury 754 levels occurring from 1990 to 1994). In the Caniapiscau 755 area, where the near absence of aquatic vegetation does not 756 constitute a preferred habitat for the northern pike, no small 757 specimens were caught in pre-impoundment conditions (at 5 758 sampling stations) nor in the reference lake (table 5). Some 759 small specimens were however caught in Caniapiscau 760 reservoir in 1982, 1987, 1995 and 1999, representing a 761 significant increase compared to pre-impoundment, before, 762 during, and after peak mercury levels which occurred from 7631991 to 1995 .

764 For walleye of Robert-Bourassa reservoir, the \% of 765 small specimens decreased significantly for a number of 766 years following impoundment (from 1980 to 1988), after 767 which values not significantly different from pre768 impoundment were obtained the last two sampling years 769 (1992 and 1996), thus during and after peak mercury levels 770 occurring from 1988 to 1992 (Table 6). After an initial 771 significant decrease during filling of Opinaca reservoir 772 (1980), the \% of small walleye remained not significantly 773 different from pre-impoundment values from 1981 to 1992 , 774 corresponding to before and during peak mercury levels 775 (occurring from 1984 to 1992). A significant increase in the $776 \%$ of small walleye was observed for the last year of 777 monitoring (1996), shortly after peak mercury levels.

778 In Caniapiscau reservoir, significantly lower 779 proportions of small lake trout were obtained 9 years after 780 impoundment, from 1991 to 1999 , corresponding to the 781 period of peak mercury levels occurring from 1989 to 1999 782 (Table 7).

783 In summary, with the exception of lake trout in the 784 Caniapiscau reservoir and lake whitefish of the Robert785 Bourassa reservoir, significant increases in the \% of small 786 specimens or values not significantly different from pre787 impoundment conditions were obtained during and after 788 peak mercury levels for the fish species and reservoirs 789 monitored. These data do not indicate a systematic effect of 790 mercury on fish recruitment at the population level.

791

\section{Discussion}

793 It has been shown that the post-impoundment increase in 794 mercury levels is due to bacterial decomposition of flooded 795 organic matter, such as humus, mosses, grasses and leaves
796 of shrubs and trees (Kelly et al., 1997; Hall et al., 2005). 797 This bacterial activity transforms the inorganic mercury 798 contained in this organic matter into methylmercury, a form 799 that is highly assimilated by aquatic organisms (Bodaly et 800 al. 1984, 2007; Lucotte et al. 1999). Methylmercury 801 production is biomagnified through the food chain and 802 reaches maximum concentrations in piscivorous fish 803 (Lucotte et al. 1999). The increase is temporary, however, as 804 readily decomposable organic matter is rapidly depleted 805 (Lucotte et al. 1999; St-Louis et al., 2004). Such a decrease 806 has also been observed in other reservoirs in Canada or the 807 Amazon watershed (Anderson et al. 1995; Malm 2006).

808

\section{Fish density}

810 Despite these periods of increase in fish mercury levels, 811 increases in lake whitefish, longnose sucker and northern 812 pike fishing yields (tables 3 to 5), as well as increases in 813 yields of the fish community as a whole (all species caught 814 combined; Deslandes et al. 1995), have been observed in the 815 three La Grande complex reservoirs. This increase in fishing 816 yields has also been observed in more than 100 reservoirs, 817 as stated in the review of Randall et al. (1995), and is 818 associated with the biological boom that usually occurs after 819 the flooding of organic matter. Indeed, the increases in both 820 mercury levels and fishing yields were related to reservoir 821 impoundment, as they were not observed in the reference 822 lakes. The same decomposition of flooded organic material 823 that causes increased mercury levels also releases nutrients 824 into the water column; this stimulates phytoplankton 825 production, which in turn stimulates zooplankton 826 production, with positive effects as far up as fish 827 populations (Schetagne 1994). Lake whitefish CPUEs in 828 Robert-Bourassa and Opinaca reservoirs were positively 829 correlated with total phosphorus and chlorophyll $a$ 830 concentrations, as well as with zooplankton biomass 831 (Deslandes et al. 1994). At the same time, benthic 832 invertebrate production, which is also strongly stimulated by 833 the great amount of available flooded organic matter, further 834 enhances the biological boom typical of reservoir 835 impoundment.

836 Significant decreases in fishing yields of lake whitefish 837 in the Caniapiscau reservoir and of walleye in the Robert838 Bourassa and Opinaca reservoirs were observed for the first 839 few years following impoundment, and the significant 840 increases in yields of lake whitefish, of northern pike, and of 841 the fish population as a whole in all 3 reservoirs were 842 usually observed only 3 or 4 years after impoundment. This 843 delay may be explained simply by the dilution of initial fish 844 populations by the impoundments, as aquatic area increased 845 by factors ranging from 3.5 to 12 (Table 1). The initial water 846 volume of these reservoirs was roughly estimated to vary 847 from less than 1\% (Robert-Bourassa reservoir) to about 10\% 848 (Opinaca) of the after-impoundment water volume. Since 849 CPUE reflects fish density, the increased aquatic area (and 850 water volume) must be taken into account to properly assess 851 the increase in reservoirs' total fish abundance. For the La 852 Grande complex reservoirs, fish abundance must have 853 increased greatly, and rapidly, to cause higher CPUEs, 
854 despite such marked increases in aquatic area and volume. 855 Indeed, increases in CPUE were usually observed as early 856 as 3 years after flooding, and our age data show that very 857 few fish younger than 2 or 3 years old are caught by the gill 858 nets used.

859 It has been well documented that the biological boom 860 gradually tapers off, as does the increase in mercury, 861 because readily decomposable organic matter is rapidly 862 depleted. Water quality changes resulting from the leaching 863 and decomposition of flooded organic matter, such as 864 dissolved oxygen depletion, increased phosphorus and 865 increased chlorophyll $a$ (a surrogated for phytoplankton 866 biomass), peaked 2 to 3 years after impoundment and were 867 virtually over after 9 to 10 years in Robert-Bourassa and 868 Opinaca reservoirs (Schetagne 1994; Lucotte et al. 1999). In 869 Caniapiscau reservoir, impounded over a longer period and 870 located in a colder region, these changes peaked after 2 to 87110 years and were over after 10 to 14 years (Lucotte et al. 872 1999).

873 After the initial increase in longnose sucker density in 874 Robert-Bourassa reservoir, the subsequent decrease 875 occurred more rapidly and led, for a number of years, to 876 fishing yields below initial values or surrounding natural 877 lake values. In this particular case, this species may have 878 been subject to over-predation by walleye and northern pike, 879 as well as to competition for benthic food by lake whitefish, 880 three species that remained in higher relative abundance 88117 years after impoundment (Deslandes and Fortin 1994).

882 For walleye in Robert-Bourassa and Opinaca reservoirs, 883 although post-impoundment CPUEs increased markedly 884 after the initial decrease caused by dilution, they did not 885 surpass pre-impoundment CPUEs. This may have involved 886 a redistribution of the walleye in the former beds of lakes 887 and rivers outside the submerged-tree zone, as suggested by 888 the results of a complementary study (Plante 1982). The 889 results of another complementary study done in 1996 890 (Doyon and Belzile, 1998) showed that the use of littoral 891 sampling stations may have led to an underestimation of 892 relative abundance for walleye after impoundment, as this 893 species is more pelagic. The choice of littoral stations for 894 the monitoring was guided by benthic and fish production, 895 which is concentrated in relatively shallow habitats in these 896 oligotrophic northern environments (Dumont 1977; Johnson 897 1975).

898 The initial decrease in lake trout fishing yield in 899 Caniapiscau reservoir can be related to poor recruitment, 900 which is linked to a form of homing toward initial spawning 901 grounds, making the after-impoundment location of new 902 spawning sites difficult for this species (Horrall 1981; 903 Foster 1985; Gendron and Belanger 1993). It may also be 904 related to severe winter drawdown, which may reach $13 \mathrm{~m}$ 905 in this reservoir (Deslandes et al. 1994; Doyon et al. 1998). 906 There are many examples of drawdown that have led to a 907 drastic reduction in egg survival (Rawson 1945; Martin 908 1955; DeRoche 1969; Lacasse and Gilbert 1992) or to the 909 elimination of a lake trout population in reservoirs. One 910 example is the $10-\mathrm{m}$ drawdown that has led to the 911 elimination of a lake trout population from Bark Lake
912 (Wilton 1985). A number of years after impoundment, this 913 species may have found alternative spawning grounds in 914 tributaries (Lemieux and Doyon 1998). This would explain 915 why lake trout CPUE increased to 1.7 in 1999 (Table 7), 916 while mercury levels remained at maximum values for 9179 years (not significantly different mercury concentrations 918 from 1991 to 1999). Reproduction of lake trout in this 919 reservoir is clearly not related to mercury levels, as initial 920 decreasing density is associated with low initial mercury 921 levels, while subsequent increasing density is associated 922 with maximum mercury levels. Such high mercury levels 923 did not prevent lake trout density from increasing again after 924 its initial decrease.

925

\section{Fish growth}

927 The data presented in Fig. 4 to 6 clearly show that in 928 connection with reservoir impoundment, where increased 929 nutrients produce increased biological production, threefold 930 to sevenfold increases in mercury levels did not impair 931 growth rates. The significant increases in growth found at 932 young ages for almost all the species in all reservoirs is an 933 indication that it occured in fish born during or shortly after 934 impoundment, as a consequence of the biological boom 935 mentioned earlier. This phenomenon has been often seen 936 after impoundment for piscivorous species like northern 937 pike and walleye (Machniak $1975 \mathrm{a}, \mathrm{b}$ ). The increase in prey 938 densities is directly linked to this predator growth increase. 939 This situation is generally temporary (Nelson 1974). For 940 fish in the three monitored reservoirs, growth rate patterns 941 show no relationship to mercury levels, as growth rates in 942 all species, during and after peak mercury levels, remained 943 comparable to or higher than those obtained before 944 impoundment, as well as in reference lakes. Indeed, growth 945 rates were still high 17 to 21 years after reservoir 946 impoundment, depending on species and reservoir.

947

\section{Fish condition}

949 After the impoundment of the three monitored 950 reservoirs, the increase in mercury levels did not prevent 951 fish condition factors ( $\mathrm{K}$ factor) from increasing compared 952 to pre-impoundment or reference lake values. These 953 increases closely followed the pattern of change in 954 chlorophyll $a$, an indicator of the post-impoundment 955 nutrient and phytoplankton biomass increases resulting from 956 the decomposition of readily decomposable flooded organic 957 matter (Lucotte et al. 1999). For the piscivorous northern 958 pike and walleye in Robert-Bourassa and Opinaca 959 reservoirs, peak mercury levels are observed well after peak 960 condition factors. It has been clearly shown that, in 961 reservoirs, mercury levels in predators peak after those in 962 non-piscivorous species, as the mercury must first 963 accumulate in the prey in order to be later observed in the 964 predator (Lucotte et al. 1999; Bodaly et al. 2007). 965 Nevertheless, condition factors remained higher than or 966 equal to pre-impoundment or reference lake condition 967 values.

968

969 


\section{Fish recruitment}

971 The proportion of small specimens of the main species 972 in the three reservoirs, an indicator of recruitment, does not 973 show a relationship with mercury levels, as its values, for 974 most species and in most reservoirs, increased or remained 975 not significantly different from pre-impoundment values up 976 to 16 to 17 years after impoundment, thus during and after 977 peak mercury levels. The only major exception in 978 recruitment was observed for lake trout in Caniapiscau 979 reservoir, where the proportion of small specimens 980 decreased continuously after impoundment. However, this 981 pattern appears not to be linked to mercury levels, but rather 982 to severe water level fluctuations and the scarcity of 983 adequate spawning grounds (Gendron and Bélanger 1991).

984 Deslandes et al. (1995) have shown that increased 985 recruitment in the first years following impoundment 986 explains part of the rise in CPUE values for several species 987 in the La Grande complex reservoirs. For instance, year 988 class strength for lake whitefish, longnose sucker and 989 northern pike, increased noticeably in the Robert-Bourassa 990 reservoir (formerly named La Grande 2), while it increased 991 as well for lake whitefish, northern pike and walleye in the 992 Opinaca reservoir. This increased recruitment explains the 993 rise in the percentage of small specimens after 994 impoundment.

995

\section{Overall fish population health indices}

997 These results do not show mercury-related ill effects on 998 fish recruitment, fishing yields, fish growth rates and fish 999 condition factors at the population level, in connection with 1000 northern reservoir impoundments, despite temporary three 1001 to sevenfold increases in fish mercury levels compared to 1002 those of surrounding natural lakes. Although it could be 1003 argued that the observed fish condition or fishing yield data 1004 were not as high as they might have been with no mercury 1005 increase, there are no available data to confirm or infirm this 1006 hypothesis. It clearly remains that three to sevenfold 1007 increases in fish mercury levels did not prevent significant 1008 post-impoundment increases in fish population good-health 1009 indices, such as recruitment, condition factor, growth rate 1010 and fishing yield.

1011 These results thus do not support the conclusions of a 1012 number of authors cited in our introduction who have 1013 observed negative effects on fish growth, condition or 1014 reproduction at mercury concentrations representative of 1015 natural pristine environments. Our results do not indicate 1016 mercury-related ill effects at concentrations 3 to 7 times 1017 higher than those found in pristine northern water bodies.

1018 As stated by Friedmann et al. (1996 b) and Wiener and 1019 Spry (1996), mercury concentrations used in the laboratory 1020 are often not environmentally relevant and may be tenfold 1021 higher than in nature. This may lead to an overestimation of 1022 the toxicity of mercury in natural environments. By not 1023 showing effects on the same endpoints as assessed in 1024 laboratory experiments, such as fish condition and growth 1025 rates, our results tend to support the Harris et al. (2003) 1026 hypothesis that the toxicity of methylmercury is
1027 overestimated in laboratory studies that usually use 1028 methylmercury chloride as a model compound for 1029 methylmercury in fish, which is bound to cysteine and may 1030 be less active or toxic.

1031 In new reservoirs, the increase in nutrients and primary 1032 and secondary production related to the flooding of 1033 terrestrial soils and vegetation, which is also responsible for 1034 the mercury increase in fish, leads to a biological boom 1035 which has positive effects on fish populations. This 1036 biological boom may have prevented potential mercury1037 related ill effects.

1038

\section{ACKNOWLEDGMENTS}

1040 This paper was made possible by funding from the 1041 Mercury Agreement 1986 signed between the Crees from 1042 the Baie-James region, Hydro-Québec and the Quebec 1043 government.

1044

\section{REFERENCES}

1046

1047 ADAMS, S.M., BEVELHIMER, M.S., GREELEY, M.S., 1048 LEVINE, D.A., AND THE, S.J. 1999. Ecological risk 1049 assessment in a large river-reservoir: 6. Bioindicators 1050 of fish population health. Environ. Toxicol. Chem. $1051 \quad 18: 628-640$.

1052

1053 ANDERSON, M. R., SCRUTON, D. A., WILLIAMS, U. 1054 P., AND CURTIS, L. R. 1995. Mercury in fish in the 1055 Smallwood reservoir, Labrador, 21 years after 1056 impoundment. Water, Air, and Soil Pollution 80: 9271057930.

1058

1059 ANDERSON, R. O., AND NEUMANN, R. M. 1996. 1060 Length, weight, and associated structural indices. In 1061 Fisheries Techniques, 2nd edition, ed. B. R. Murphy 1062 and D. W. Willis: 447-482. Bethesda, Maryland: 1063 American Fisheries Society.

1064

1065 BATCHELAR, K.L., KIDD, K.A., DREVNICK. P.E., 1066 MUNKITTRICK, K.R., BURGESS, N.M., 1067 ROBERTS, A.P., AND SMITH, J.D. 2012. Evidence 1068 of impaired health in yellow perch (Perca flavescens) 1069 from a biological mercury hotspot in northeastern 1070 North America. Environmental Toxicology and 1071 Chemistry, Vol. 32, No. 3: 627-637.

1072

1073 BATCHELAR, K.L., KIDD, K.A., MUNKITTRICK, K.R., 1074 DREVNICK P.E., AND BURGESS, N.M. 2013. 1075 Reproductive health of yellow perch (Perca 1076 flavescens) from a biological mercury hotspot in Nova 1077 Scotia, Canada. Science of the Total Environment: 1078 319-327.

1079

1080 BEAMISH, R.J. 1973. Determination of age and growth of 1081 populations of the white sucker (Catostomus 1082 commersoni) exhibiting a wide range in size at 1083 maturity. J. Fish. Res. Board Can., 30(5):607-616. 
1084 BIRGE, W.J., BLACK, J.A., WESTERMAN, A.G., AND 1085 HUDSON, J.E. 1979. The effects of mercury on 1086 reproduction of fish and amphibians. In Nriagu, J. ed. 1087 The Biogeochemistry of Mercury in the Environment. 1088 Amsterdam: Elsevier/North Holland 1979:629-655.

1089

1090 BLOOM, N. S. 1992. On the chemical form of mercury in 1091 edible fish and marine invertebrate tissue. Can. J. 1092 Fish. Aquat. Sci. 49:1010-1017.

1093

1094 BODALY, R. A., AND FUDGE, R. J. P. 1999. Uptake of 1095 mercury by fish in an experimental boreal reservoir. 1096 Arch. Environ. Contam. Toxicol. 37:103-109.

1097

1098 BODALY, R.A., HECKY, R.E., AND FUDGE, R.J.P. 1099 1984. Increase in fish mercury levels in lakes flooded 1100 by the Churchill River diversion, northern Manitoba. 1101 Canadian Journal of Fisheries and Aquatic Sciences 1102 41:682-691.

1103

1104 BODALY, R. A., BEATY, K. G. HENDZEL, L. H. 1105 MAJEWSKI, A. R. PATERSON, M. J. ROLFHUS, K. 1106 R. PENN, A. F. ST. LOUIS, V. L. HALL, B. D. 1107 MATTHEWS, C. J. D. CHEREWYK, K. A. 1108 MAILMAN, M. HURLEY, J. P. SCHIFF, S. L., AND 1109 VENKITESWARAN, J. J. 2004. Experimenting with 1110 hydroelectric reservoirs. Environ. Sci. Technol. 1111 38:346A-352A.

1112

1113 BODALY, R. A., JANSEN, W. A. MAJEWSKI, A. R. 1114 FUDGE, R. J. P. STRANGE, N. E. DERKSEN, A. J., 1115 AND GREEN, D. J. 2007. Postimpoundment time 1116 course of increased mercury concentrations in fish in 1117 hydroelectric reservoirs of northern Manitoba, Canada. 1118 Arch. Environ. Contam. Toxicol. 53:379-389.

1119

1120 CASSELMAN, J.M. 1979. "The esocid cleithrum as an 1121 indicator calcified structure." Compte rendu $d u 10^{e}$ 1122 atelier sur les poissons d'eau chaude/Proceedings of 1123

1124

1125

1126

1127

1128 CRUMP, K. L., AND TRUDEAU, V. L. 2009. Mercury-

1129

1130

1131

1132

1133 DEPEW, D., BASU, N., BURGESS, N., CAMPBELL, L., 1134

1135

1136

1137

1138

1139

1140
1141 DeROCHE, S. E. 1969. Obervations of the spawning habits 1142 and early life of Lake Trout. Prog. Fish-Cult. 3 :109$1143 \quad 113$.

1144

1145 DESLANDES, J.-C., AND FORTIN, R. 1994. Optimisation 1146 du réseau de suivi environnemental des populations de 1147 poissons des milieux affectés par l'aménagement du 1148 complexe La Grande (Phase I). Département des 1149 sciences biologiques, Université du Québec à 1150 Montréal for vice-Présidence Environnement Hydro1151 Québec. 95 p.

1152 DESLANDES, J.-C., GUÉNETTE, S., AND FORTIN, R. 1153 1994. Évolution des communautés de poissons de 1154 milieux affectés par l'aménagement du complexe

1155 La Grande, Phase 1 (1977-1992). Département des 1156 sciences biologiques, Université du Québec à 1157 Montréal for Hydro-Québec. 89 p.

1158

1159 DESLANDES, J.-C., GUÉNETTE, S., PRAIRIE, Y., ROY, 1160 D., VERDON, R. AND FORTIN, R. 1995. Changes in 1161 fish populations affected by the construction of the La 1162 Grande complex (Phase I), James Bay region, Quebec. 1163 Can. J. Zool. 73: 1860- 1877.

1164

1165 DOYON, J.-F., AND BELZILE, L. 1998. Réseau de suivi 1166 environnemental du complexe La Grande (19771167 1996). Suivi des communautés de poissons et étude 1168 spéciale sur le doré (secteur ouest du territoire). 1169 Groupe conseil GENIVAR inc. for Hydro-Québec. $1170 \quad 145$ p. and appendices.

1171

1172 DOYON, J.-F., BERNATCHEZ, L., GENDRON, M., 1173 VERDON, R., AND FORTIN, R. 1998. Comparison 1174 of normal and dwarf populations of lake whitefish 1175 (Coregonus clupeaformis) with reference to 1176 hydroelectric reservoirs in northern Québec. Archiv 1177 für Hydrobiologie - Advances in Limnology 50:97-

1178

1179

1180 DREVNICK, P. E., AND SANDHEINRICH, M. B. 2003.

1181 Effects of dietary methylmercury on reproductive 1182 endocrinology of fathead minnows. Environ. Sci. 1183 Technol. 37:4390-4396.

1184 DREVNICK, P.E., CANFIELD, D.E., GORSKI, P.R., 1185 SHINNEMAN, A.L.C., ENGSTROM, D.R., MUIR, 1186 D.C.G., SMITH, G.R., GARRISON, P.J., 1187 CLECKNER, L.B., HURLEY, J.P., NOBLE, R.B., 1188 OTTER, R.R., AND ORIS, J.T., 2007. Deposition and 1189 cycling of sulfur controls mercury accumulation in Isle 1190 Royale fish. Environ. Sci. Technol. 41:7266-7272.

1191

1192 DREVNICK, P.E., ROBERTS, A.P., OTTER, R.R., 1193 HAMMERSCHMIDT, C.R., KLAPER, R., AND 1194 ORIS, J.T. 2008. Mercury toxicity in livers of northern 1195 pike (Esox lucius) from Isle Royale, USA. Comp. 1196 1197 
1198 DUBOIS, A., AND LAGUEUX, R. 1978. Étude comparée 1199 de l'âge scalaire et de l'âge otolithique du touladi 1200 (Salvelinus namaycush). Lac Mistassini, Québec. 1201 Natur. Can. 95:907-928.

1202

1203 DUMONT, P. 1977. Quelques aspects du cycle vital du 1204 grand corégone, Coregonus clupeaformis (Mitchill) de 1205 quatre lacs du territoire de la Baie James: les lacs 1206 Hélène, Nathalie, Yasinski et Alder. Masters thesis, 1207 Université du Québec à Montréal.

1208

1209 ENVIRONMENT CANADA. 1979. Analytical methods 1210 manual. Inland Waters Directorate, Ottawa.

1211

1212 FOSTER, N.R. 1985. Lake Trout Reproductive Behavior: 1213 Influence of Chemosensor Cues from Young-of-the1214 Year By-Products. Trans. Am. Fish. Soc. 114:7941215803.

1216

1217 FRIEDMANN, A.S., WATZIN, M.C., LEITER, J.C., AND 1218 BRINCK-JOHNSEN, T. 1996a. Effects of 1219 environmental mercury on gonadal function in Lake 1220 Champlain northern pike (Esox lucius). Bull Environ 1221 Contam Toxicol 56:486-492.

1222

1223 FRIEDMANN A.S., WATZIN, M.C., BRINCK-JOHNSEN, 1224 T., AND LEITER, L.C. 1996b. Low levels of 1225 methylmercury inhibit growth and gonadal 1226 development in juvenile walleye (Stizostedion 1227 vitreum). Aquat. Toxicol. 35:265-278.

1228

1229 FRIEDMANN, A.S., COSTAIN, E. K. MACLATCHY, D. 1230 L. STANSLEY, W., AND WASHUTA, E. J. 2002.

1231 Effect of mercury on general and reproductive health 1232 of largemouth bass (Micropterus salmoides) from 1233 three lakes in New Jersey. Ecotoxicol. Environ. Safety

1234

1235

1236 GENDRON, M., AND BÉLANGER, B. 1991. Étude de 1237 l'effet du marnage sur la faune ichtyenne des 1238 réservoirs Pipmuacan, Outardes-4 et Manic-5, travaux 1239 de recherche autonome 1990. Le Groupe de Recherche 1240 SEEEQ ltée, for Service ressources et aménagement 1241 du territoire, Vice-présidence Environnement, Hydro1242 Québec. $108 \mathrm{p}$.

1243 GENDRON, M., AND BÉLANGER, B. 1993. Étude de 1244 l'état des populations de touladi dans les réservoirs. Le 1245 Groupe de Recherche SEEEQ ltée, for Service 1246 ressources et aménagement du territoire, Vice1247 1248

1249 HALL, B.D., BODALY, R.A., FUDGE, R.J.P., RUDD, 1250 J.W.M., AND ROSENBERG, D.M. 1997. Food as the 1251 dominant pathway of methylmercury uptake by fish. 1252 Water Air Soil Pollut. 100:13-24.
1254 HALL, B.D., ST. LOUIS, V.L., ROLFHUS, K.R., 1255 BODALY, R.A., BEATY, K.G. AND PATERSON, 1256 M.J. 2005. The impact of reservoir creation on the 1257 biogeochemical cycling methyl and total mercury in 1258 boreal upland forests. Ecosystems 8:248-266.

1259

1260 HAMMERSCHMIDT, C. R., SANDHEINRICH, M. B. 1261 WIENER, J. G., AND RADA, R. G. 2002. Effects of 1262 dietary methylmercury on reproduction of fathead 1263 minnows. Environ. Sci. Technol. 36:877-883.

1264

1265 HARRIS, H.H., PICKERING, I.J. AND GEORGE, G.N. 1266 2003. The chemical form of mercury in fish. Science. 1267 29: 1203

1268

1269 HORRALL， R.M. 1981. Behavioral Stock-Isolating 1270 Mechanisms in Great Lakes Fishes with Special 1271 Reference to Homing and Site Imprinting. Can. J. 1272 Fish. Aquat. Sci. 38: 1481 - 1496.

1273

1274 HOUCK, A. AND CECH, J. J. 2004. Effects of dietary 1275 methylmercury on juvenile Sacramento blackfish 1276 bioenergetics, Aquat Toxicol, 69: 107-123.

1277

1278 JOHNSON, L. 1975. Distribution of fish species in Great 1279 Bear Lake, Northwest Territories, with reference to 1280 zooplankton, benthic invertebrates, and environmental 1281 conditions. J. Fish. Res. Board Can. 32: 1989-2004.

1282

1283 KELLY, C.A., RUDD, J.W.M., BODALY, R.A., ROULET, 1284 N.P., ST LOUIS, V.L., HEYES, A., MOORE, T.R., 1285 SCHIFF, S., ARAVENA, R., SCOTT, K.J., DYCK, 1286 B., HARRIS, R., WARNER, B., AND EDWARDS, 1287 G. 1997. Increases in fluxes of greenhouse gases and 1288 methylmercury following flooding of an experimental 1289 reservoir. Environ. Sci. Technol. 31:1334-1344.

1290

1291 LACASSE, S. AND GILBERT, L. 1992. Évaluation de 1292 l'impact du marnage sur la reproduction du Touladi au 1293 lac Mondonac. G.D.G. Environnement ltée, Hydro1294 Québec. 82 p. et annexes.

1295

1296 LAROSE, C., CANUEL, R., LUCOTTE, M., AND DI 1297 GIULIO, R.T. 2008. Toxicological effects of 1298 methylmercury on walleye (Sander vitreus) and perch 1299 (Perca flavescens) from lakes of the boreal forest. $1300 \quad$ Comp. Biochem. Physiol. Part C 147:139-149.

1301

1302 LASORSA, B., AND ALLEN-GIL, S. 1995. The 1303 methylmercury to total mercury ratio in selected 1304 marine, freshwater and terrestrial organisms. Water, 1305 Air and Soil Pollution 80:905-913.

1306

1307 LATIF, M.A., BODALY, R.A., JOHNSON, T.A., AND 1308 FUDGE, R.J.P. 2001. Effects of environmentally and 1309 maternally derived methylmercury on the embryonic 1310 and larval stages of walleye (Stezostedion vitreum).

1311 Environ Poll: 111:139-148. 


\section{2}

1313 LEMIEUX, C., AND DOYON, J.F. 1998. Suivi des 1314 tributaires aménagés du réservoir Caniapiscau (1997). 1315 Report by Groupe conseil GENIVAR inc for 1316 Hydro-Québec, 63 p. and appendices.

1317

1318 LINDQVIST, O. 1991. Mercury in the Swedish 1319 environment; recent research on causes, consequences 1320 and corrective methods. Water, Air and Soil Pollution $1321 \quad 55: 1-262$.

1322 LUCOTTE, M., SCHETAGNE, R., THÉRIEN, N.,

1323

1324

1325

1326

1327

1328 MACHNIAK, K. 1975a. The effects of hydroelectric

1329

1330

1331

1332

1333

1334

1335 MACHNIAK, K. 1975b. The effects of hydroelectric

1336

1337

1338

1339

1340

1341

1342 MALM, O. 2006. Mercury in different Amazon reservoirs,

1343

1344

1345

1346

1347 MARTIN, N. V. 1955. The effect of drawdowns on Lake

1348

1349

1350 developments on the biology of northern fishes (reproduction and population dynamics) III. Yellow walleye Stizostedion vitreum vitreum (Mitchill). A literature review and bibliography. Fish. Mar. Serv. Res. Div. Tech. Rep. No 529.

1351 MASSÉ, G. 1979. Identification des vrais et des faux annuli 1352 sur les écailles du Grand Brochet (Esox lucius L.) et sa 1353 croissance dans le fleuve Saint-Laurent, près de 1354 Montréal, Québec. Masters thesis, Université du 1355

1356

1357 MELA, M., RAND, M.A.F., VENTURA, D.F., 1358 CARVALHO, C.E.V., PELLETIER, E., AND 1359 OIVEIRA RIBEIRO, C.A. 2007. Effects of dietary 1360 methylmercury on liver and kidney histology in the 1361 1362 1363

1364 MORIN, R., DODSON, J.J., AND POWER, G. 1982. Life 1365 history variations of anadromous cisco (Coregonus 1366 artedii), lake whitefish (C. clupeaformis), and round 1367 1368 1369 whitefish (Prosopium cylindraceum) populations of eastern James-Hudson Bay. Can. J. Fish. Aquat. Sci. 39: 958-967.
1370

1371 MUNN, M.D., AND SHORT, T.M. 1997. Spatial 1372 heterogeneity of mercury bioaccumulation by walleye 1373 in Franklin D. Roosevelt Lake and the upper Columbia 1374 River, Washington. Trans. Am. Fish. Soc. 126:477-

1375

1376

1377 NELSON, W.R. 1974. Age, growth and maturity of thirteen 1378 species of fish from lake Oahe during the early years 1379 of impoundment, 1963-1968.U. S. Fish. Wild. Serv. $1380 \quad$ Tech. Pap. No. 77.

1381

1382 PÉPIN, S., AND LÉVESQUE, F. 1985. Technique de 1383 détermination de l'âge des dorés applicable aux 1384 populations de cette espèce au Québec. Ministère du 1385 Loisir, de la Chasse et de la Pêche, Québec. 33 p.

1386 PLANTE, M. 1982. Résultats des activités spéciales de 1387 pêche de la saison 1981 du Réseau de surveillance 1388 écologique. Direction Environnement, Société 1389 d'énergie de la Baie James. 22 p.

1390

1391 POWER, G. 1978. Fish population structure in arctic lakes. 1392 Journal of the Fisheries Research Board of Canada 1393 35:53-39.

1394

1395 RANDALL, R.G., KELSO, J.R.M., AND MINNS, C.K. 1396 1995. Fish production in freshwaters: Are rivers more 1397 productive than lakes? Canadian Journal of Fisheries 1398 and Aquatic Sciences 52:631- 643.

1399

1400 RAWSON, D. W. 1945, Further investigation of the effect 1401 of power development on the fisheries of lake 1402 Minnewanka, Banff. Can. Dep. Mines. Resour., Nat. 1403 Parks Bur. Ms. Rep.

1404

1405 RICKER, W.E. 1980. Computation and interpretation of 1406 biological statistics of fish populations. Fisheries 1407 Research Board of Canada Bulletin 191.400 p.

1408

1409 RODGERS, D.W. 1994. You are what you eat and a little 1410 bit more: bioenergetics-based models of 1411 methylmercury accumulation in fish revisited. In: 1412 Watras C.J., and Huckabee, J.W., eds. Mercury 1413 pollution; integration and synthesis. Boca Raton, 1414 Florida: Lewis Publishers. p .427-439.

1415

1416 SCHERER, E., ARMSTRONG, F.A.J., AND NOWAK, 1417 S.H. 1975. Effects of mercury-contaminated diet upon 1418 walleyes, Stizostedion vitreum vitreum (Mitchill). 1419 Can. Fish. Mar. Serv. Res. Dev. Branch, Winnipeg, 1420 1421

1422 SCHETAGNE, R. 1994. Water quality modifications after 1423 impoundment of some large northern reservoirs. 1424 Archiv für Hydrobiologie - Advances in 1425 1426 Limnology 40:223-229. 
1427 SCHETAGNE, R., AND VERDON, R. 1999. Post1428 impoundment evolution of fish mercury levels at the 1429 La Grande complex, Québec, Canada (from 1978 to 1430 1996). In: Lucotte et al., eds. Mercury in the 1431 Biogeochemical Cycle: Natural Environments and 1432 Hydroelectric reservoirs of Northern Québec, Berlin: 1433

1434

1435 SCHETAGNE, R., AND THERRIEN, J. 2013. Suivi 1436 environnemental du complexe La Grande. Évolution des 1437 teneurs en mercure dans les poissons. Rapport synthèse 1438 1978-2012. GENIVAR inc. et Hydro-Québec Production. $1439174 \mathrm{p}$

1440

1441 SCHEUHAMMER, A.M., BASU, N., EVERS, D.C., 1442 HEINZ, G.H., SANDHEINRICH, M., AND BANK, 1443 M.S. 2012. Toxicology of mercury in fish and 1444 wildlife: recent advances. In: Bank M.S., ed. Mercury 1445 in the Environment: Pattern and Process. Berkeley: 1446 University of California Press.

1447

1448 SCHEUHAMMER, A., BRAUNE, B., CHAN, H.M., 1449 FROUIN, H., KREY, A., LETCHER, R., LOSETO, 1450 L., NOËL, M., OSTERTAG, S., ROSS, P., AND 1451 WAYLAND, M. 2014. Recent progress on our 1452 understanding of the biological effects of mercury in 1453 fish and wildlife in the Canadian Arctic. Sci. Total 1454

1455

1456 SCOTT, G.R., AND SLOMAN, K.A. 2004. The effects of 1457 environmental pollutants on complex fish behavior: 1458 integrating behavioural and physiological indicators of 1459

1460

1461 SPRY, D.J., AND WIENER, J.G. 1991. Metal 1462 bioavailability and toxicity to fish in low-alkalinity 1463 lakes-A critical review. Environ Pollut. 71:243-304.

1464

1465 ST. LOUIS, V.L., RUDD, J.W.M., KELLY, C.A., 1466 BODALY, R.A., PATERSON, M.J., BEATY, K.G., 1467 HESSLEIN, R.H., HEYES, A.W. AND MAJEWSKI, 1468 A,R. 2004. The rise and fall of mercury methylation in 1469 an experimental reservoir. Environ Sci Technol $1470 \quad 38: 1348-1358$

1471

1472 TREMBLAY, G., LEGENDRE, P., VERDON, R., 1473 DOYON, J.-F., AND SCHETAGNE, R. 1998. 1474 Polynomial regression analysis with indicator 1475 variables for the interpretation of monitoring data on 1476 mercury levels in fish. Biogeochemistry 40:189-201.

1477

1478 VERDON, R., AND MAGNIN, É. 1977. Croissance en 1479 longueur du meunier noir Catostomus commersoni 1480 commersoni (Lacépède) du lac Croche dans les 1481 Laurentides, Québec. Nat. Can. 104:187-195.
1484 WATRAS, C.J., BLOOM, N.S., HUDSON, R.J.M., 1485 GHERINI, S., MUNSON, R., CLAAS, S.A., 1486 MORRISON, K.A., WIENER, J.G., FITZGERALD, 1487 W.F., MASON, R., VANDAL, G., POWELL, D., 1488 RADA, R., RISLOV, L., WINFREY, M., ELDER, J., 1489 KRABBEMHOFT, D., ANDREN, A.W., BABIARZ, 1490 C., PORCELLA, D.B., AND HUCKABEE, J.W. 1491 1994. Sources and fates of mercury and 1492 methylmercury in Wisconsin lakes. In Watras, C.J., 1493 and Huckabee, J.W., eds. Mercury Polllution 1494 Integration and Synthesis. Boca Raton, Florida: Lewis 1495

1496

1497 WEIS, J.S. 2009. Reproductive, developmental, and 1498 neurobehavioral effects of methylmercury in fishes. 1499 Journal of Environmental Science \& Health, Part C 1500 Environmental Carcinogenesis \& Ecotoxicology 1501

1502

1503 WEIS, J.S., BERGEY, L., REICHMUTH, J., AND 1504 CANDELMO, A. 2011. Living in a contaminated 1505 estuary: Behavioral changes and ecological 1506 consequences for five species. BioScience 61:375-385.

1507

1508 WEIS, J.S. AND CANDELMO, A. 2012. Pollutants and 1509 fish predator/prey behavior: A review of laboratory 1510 and field approaches. Current Zoology 58 (1): 9-20.

1511

1512 WIENER, J.G., AND SPRY, D.J. 1996. Toxicological

1513 significance of mercury in freshwater fish. In W.N.

1514 Beyer, G.H. Heinz, and A.W. Redmon-Norwood, eds.

1515 Environmental contaminants in wildlife: Interpreting

1516 tissue concentrations, 297-339. Boca Raton, Florida:

1517 CRC Press.

1518

1519 WIENER, J.G., KRABBENHOFT, D.P. HEINZ, G.H., 1520 AND SCHEUHAMMER, A.M. 2003. Ecotoxicology 1521 of mercury. In D.J. Hoffman, B.A. Rattner, G.A. 1522 Burton, Jr., and J. Cairns, Jr., eds. Handbook of 1523 ecotoxicology, 2nd edition, 409-463. Boca Raton, 1524 Florida: CRC Press.

1525

1526 WIENER, J.G., KNIGHTS, B.C., SANDHEINRICH, M.B., 1527 JEREMIASON, J.D., BRIGHAM, M.E., 1528 ENGSTROM, D.R., WOODRUFF, L.G., CANNON, 1529 W.F., AND BALOGH, S.J. 2006. Mercury in soils, 1530 lakes, and fish in Voyageurs National Park 1531 (Minnesota): importance of atmospheric deposition 1532 and ecosystem factors. Environ. Sci. Technol.

1533

1534

1535 WILTON, M.L, 1985. Water drawdown and its effects on 1536 lake trout (Salvelinus namaycush) reproduction in 1537 three south-central Ontario lakes. Fisheries Technical 1538 Report Series 20.9 p. 
Table 1. Characteristics of La Grande complex reservoirs (Phase I) at their maximum levels.

\begin{tabular}{|c|c|c|c|c|c|c|c|c|}
\hline Reservoir & $\begin{array}{c}\text { Mean annual } \\
\text { drawdown } \\
\text { observed } \\
(\mathrm{m}) * \\
\end{array}$ & $\begin{array}{l}\text { Reservoir } \\
\operatorname{area}\left(\mathrm{km}^{2}\right)\end{array}$ & $\begin{array}{c}\text { Land } \\
\text { area flooded } \\
\left(\mathbf{k m}^{\mathbf{2})} * *\right.\end{array}$ & $\begin{array}{c}\text { Mean depth } \\
\text { (m) }\end{array}$ & $\begin{array}{c}\text { Volume } \\
\left(\mathbf{k m}^{3}\right) * * *\end{array}$ & $\begin{array}{c}\text { Theoretical } \\
\text { residence } \\
\text { time } \\
\text { (month) } \\
\end{array}$ & $\begin{array}{c}\text { Mean } \\
\text { annual } \\
\text { flow } \\
\left(\mathrm{m}^{3} / \mathrm{s}\right) \\
\end{array}$ & $\begin{array}{l}\text { Filling } \\
\text { period }\end{array}$ \\
\hline Robert-Bourassa & $3.3(7.7)$ & 2,835 & $2,630(92 \%)$ & 22.0 & 61.7 & 6.9 & 3,374 & $78-11$ to $79-12$ \\
\hline La Grande 3 & $5.5(12.2)$ & 2,420 & $2,175(90 \%)$ & 24.4 & 60.0 & 11.0 & 2,064 & $81-04$ to $84-08$ \\
\hline La Grande 4 & $8.0(11.0)$ & 765 & $700(89 \%)$ & 29.4 & 19.5 & 4.8 & 1,534 & $83-03$ to $83-11$ \\
\hline Opinaca & $3.6(4.0)$ & 1,040 & $740(71 \%)$ & 8.2 & 8.4 & 3.8 & 845 & $80-04$ to $80-09$ \\
\hline Caniapiscau & $2.1(12.9)$ & 4,275 & $3,430(80 \%)$ & 16.8 & 53.8 & 25.8 & 790 & $81-10$ to $84-09$ \\
\hline
\end{tabular}

* Maximum drawdown in parentheses.

** $\quad$ Percentage of land area flooded in parentheses.

*** Values include dead storage. 
Table 2. Range of mean total mercury levels for standardized length fish for major species in natural lakes of the La Grande complex area.

\begin{tabular}{|c|c|c|c|c|c|c|c|c|}
\hline \multirow[b]{2}{*}{$\begin{array}{c}\text { Species } \\
\text { (standardized length) }\end{array}$} & \multicolumn{4}{|c|}{ Western Sector } & \multicolumn{4}{|c|}{ Eastern Sector } \\
\hline & $\begin{array}{l}\text { Number of } \\
\text { fish }\end{array}$ & $\begin{array}{l}\text { Number of } \\
\text { lakes }\end{array}$ & $\begin{array}{c}\text { Range of average } \\
\text { levels } \\
\left(\mu \mathrm{g} . \mathrm{g}^{-1}\right)\end{array}$ & $\begin{array}{c}\text { Global average } \\
\text { level } \\
\left(\mu \mathrm{g} \cdot \mathrm{g}^{-1}\right)\end{array}$ & Number of fish & $\begin{array}{l}\text { Number of } \\
\text { lakes }\end{array}$ & $\begin{array}{c}\text { Range of average } \\
\text { levels } \\
\left(\mu \mathrm{g} . \mathrm{g}^{-1}\right)\end{array}$ & $\begin{array}{c}\text { Global average } \\
\text { level } \\
\left(\mu \mathrm{g} \cdot \mathrm{g}^{-1}\right)\end{array}$ \\
\hline Lake whitefish (400 mm) & 503 & 21 & $0.05-0.20$ & 0.11 & 187 & 8 & $0.10-0.30$ & 0.16 \\
\hline Longnose sucker (400 mm) & 182 & 7 & $0.12-0.22$ & 0.12 & 246 & 9 & $0.06-0.20$ & 0.13 \\
\hline Northern pike (700 mm) & 373 & 18 & $0.30-0.93$ & 0.60 & 120 & 4 & $0.36-0.92$ & 0.59 \\
\hline Walleye (400 mm) & 353 & 13 & $0.30-1.02$ & 0.59 & & & & \\
\hline Lake trout $(600 \mathrm{~mm})$ & 131 & 7 & $0.23-0.89$ & 0,57 & 254 & 10 & $0.52-1.11$ & 0.72 \\
\hline
\end{tabular}


Table 3. Total mercury concentration ( \pm confidence interval[n]) at $400 \mathrm{~mm}$, fishing yields (CPUE $\pm \mathrm{SD}[\mathrm{n}])$, condition factor $\mathrm{K}(300-500 \mathrm{~mm}, \pm \mathrm{SD}[\mathrm{n}])$ and small specimen proportions $(<250 \mathrm{~mm}, \pm \mathrm{SD}[\mathrm{n}])$ for lake whitefish in the major La Grande reservoirs and the reference lakes.

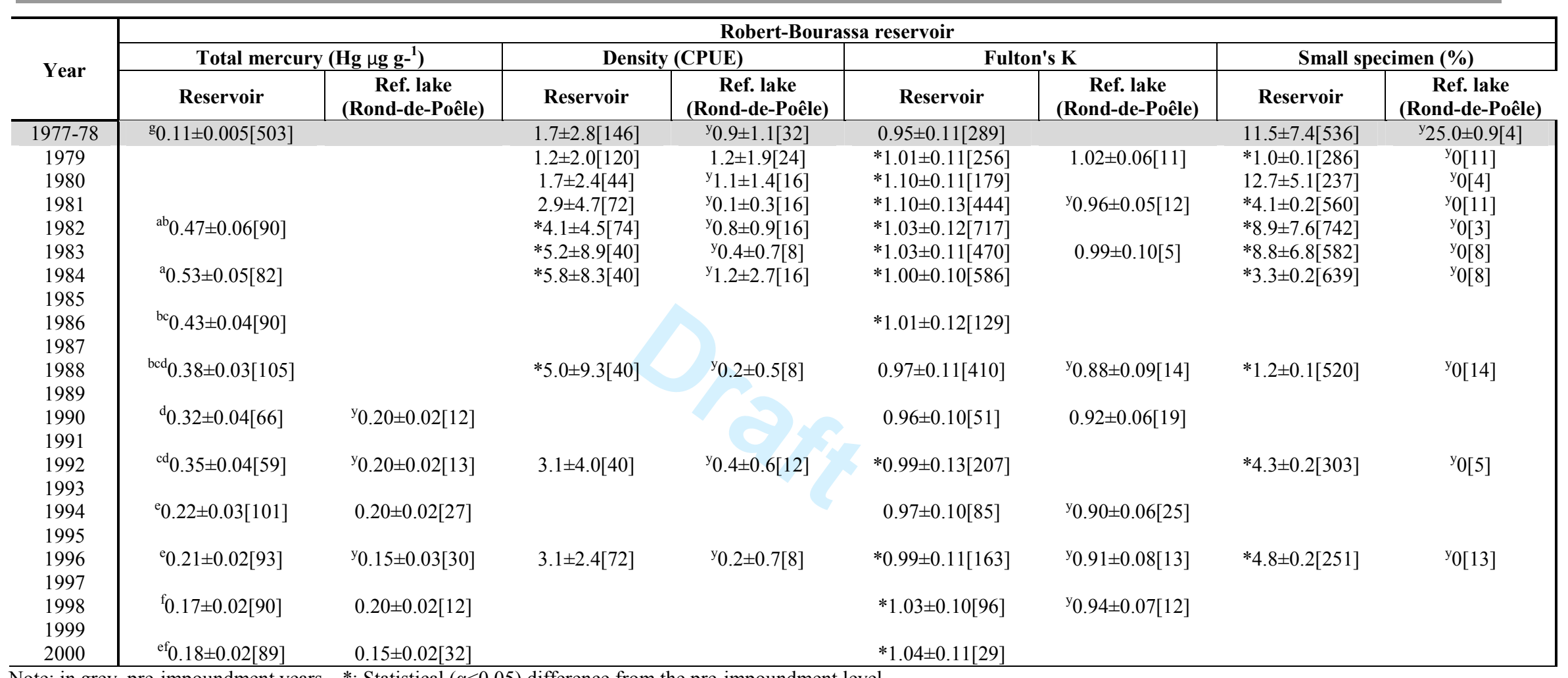

Note: in grey, pre-impoundment years. *: Statistical $(\alpha<0.05)$ difference from the pre-impoundment level.

y: Statistical $(\alpha<0.05)$ difference between reservoir and natural lake values by year.

Letters attributed to mercury levels in reservoir indicate the results of year to year multiple comparisons of means where the letter a is given to the highest value and where levels with different letters are significantly different $(\alpha<0.05)$. 
Table 3 (cont.). Total mercury concentration ( \pm confidence interval[n]) at $400 \mathrm{~mm}$, fishing yields $(\mathrm{CPUE} \pm \mathrm{SD}[\mathrm{n}])$, condition factor $\mathrm{K}$ (300-500 mm, $\pm \mathrm{SD}[\mathrm{n}])$ and small specimen proportions $(<250 \mathrm{~mm}, \pm \mathrm{SD}[\mathrm{n}])$ for lake whitefish in the major La Grande reservoirs and the reference lakes.

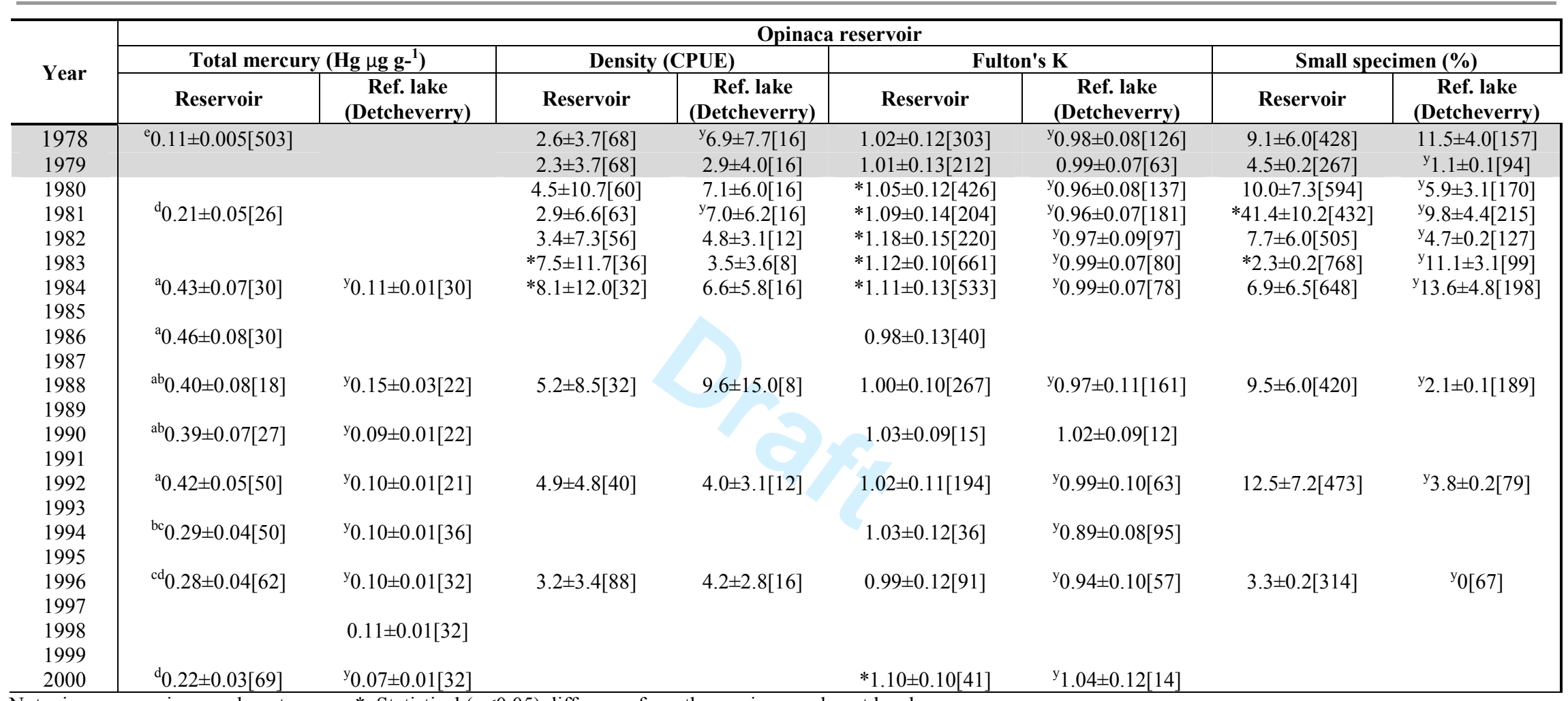

Note: in grey, pre-impoundment years. *: Statistical $(\alpha<0.05)$ difference from the pre-impoundment level.

y: Statistical $(\alpha<0.05)$ difference between reservoir and natural lake values by year.

Letters attributed to mercury levels in reservoir indicate the results of year to year multiple comparisons of means where the letter a is given to the highest value and where levels with different letters are significantly different $(\alpha<0.05)$. 
Table 3. (cont.) Total mercury concentration ( \pm confidence interval[n]) at $400 \mathrm{~mm}$, fishing yields (CPUE $\pm \mathrm{SD}[\mathrm{n}])$, condition factor $\mathrm{K}$ (300-500 mm, $\pm \mathrm{SD}[\mathrm{n}])$ and small specimen proportions $(<250 \mathrm{~mm}, \pm \mathrm{SD}[\mathrm{n}])$ for lake whitefish in the major La Grande reservoirs and the reference lakes.

\begin{tabular}{|c|c|c|c|c|c|c|c|c|}
\hline \multirow{3}{*}{ Year } & \multicolumn{8}{|c|}{ Caniapiscau reservoir } \\
\hline & \multicolumn{2}{|c|}{ Total mercury $\left(\mathrm{Hg} \mu \mathrm{g} \mathrm{g}-{ }^{1}\right)$} & \multicolumn{2}{|c|}{ Density (CPUE) } & \multicolumn{2}{|c|}{ Fulton's K } & \multicolumn{2}{|c|}{ Small specimen (\%) } \\
\hline & Reservoir & $\begin{array}{l}\text { Ref. lake } \\
\text { (Hazeur) }\end{array}$ & Reservoir & $\begin{array}{l}\text { Ref. lake } \\
\text { (Hazeur) }\end{array}$ & Reservoir & $\begin{array}{l}\text { Ref. lake } \\
\text { (Hazeur) }\end{array}$ & Reservoir & $\begin{array}{l}\text { Ref. lake } \\
\text { (Hazeur) }\end{array}$ \\
\hline $\begin{array}{l}1980 \\
1981\end{array}$ & ${ }^{\mathrm{e}} 0.16 \pm 0.01[174]$ & & $\begin{array}{c}9.8 \pm 8.5[48] \\
13.0 \pm 11.3[48]\end{array}$ & & $\begin{array}{c}0.87 \pm 0.07[560] \\
0.87 \pm 0.06[1021]\end{array}$ & & $\begin{array}{c}18.9 \pm 5.3[183] \\
25.9 \pm 15.5[1248]\end{array}$ & \\
\hline $\begin{array}{l}1982 \\
1983 \\
1984 \\
1985 \\
1986\end{array}$ & & & $* 5.1 \pm 6.9[64]$ & $6.6 \pm 7.1[16]$ & $0.88 \pm 0.08[260]$ & ${ }^{\mathrm{y}} 0.96 \pm 0.07[44]$ & $28.6 \pm 10.0[490]$ & ${ }^{\mathrm{y}} 17.2 \pm 4.6[151]$ \\
\hline $\begin{array}{l}1987 \\
1988\end{array}$ & ${ }^{\mathrm{ab}} 0.38 \pm 0.07[35]$ & ${ }^{\mathrm{y}} 0.16 \pm 0.01[32]$ & $* 5.4 \pm 7.3[40]$ & $7.6 \pm 7.4[12]$ & $* 1.01 \pm 0.12[285]$ & ${ }^{\mathrm{y}} 0.90 \pm 0.08[77]$ & $* 8.4 \pm 5.2[346]$ & ${ }^{y_{3}} .2 \pm 0.2[126]$ \\
\hline $\begin{array}{l}1989 \\
1990\end{array}$ & ${ }^{\mathrm{a}} 0.45 \pm 0.08[29]$ & ${ }^{\mathrm{y}} 0.20 \pm 0.02[29]$ & & & $* 0.93 \pm 0.13[48]$ & & & \\
\hline $\begin{array}{l}1991 \\
1992\end{array}$ & ${ }^{\mathrm{a}} 0.47 \pm 0.09[29]$ & ${ }^{\mathrm{y}} 0.16 \pm 0.01[30]$ & $* 17.8 \pm 28.8[24]$ & $8.2 \pm 5.6[8]$ & $0.90 \pm 0.12[231]$ & $0.88 \pm 0.08[35]$ & $* 64.3 \pm 16.2[1139]$ & ${ }^{\mathrm{y}} 19.8 \pm 4.2[111]$ \\
\hline $\begin{array}{l}1993 \\
1994\end{array}$ & ${ }^{\mathrm{bc}} 0.29 \pm 0.04[40]$ & ${ }^{\mathrm{y}} 0.16 \pm 0.01[31]$ & $10.9 \pm 9.5[48]$ & $16.6 \pm 15.4[24]$ & $* 0.96 \pm 0.10[330]$ & ${ }^{\mathrm{y}} 0.89 \pm 0.09[71]$ & $* 37.5 \pm 13.2[741]$ & $40.0 \pm 11.8[577]$ \\
\hline $\begin{array}{l}1995 \\
1996\end{array}$ & ${ }^{\mathrm{d}} 0.21 \pm 0.03[58]$ & ${ }^{\mathrm{y}} 0.12 \pm 0.01[33]$ & $12.0 \pm 5.9[55]$ & ${ }^{y_{2} .6 \pm 7.8[12]}$ & $* 0.91 \pm 0.09[382]$ & ${ }^{\mathrm{y}} 0.83 \pm 0.09[106]$ & $* 30.0 \pm 12.7[767]$ & $28.9 \pm 8.3[339]$ \\
\hline $\begin{array}{l}1997 \\
1998\end{array}$ & ${ }^{\mathrm{cd}} 0.24 \pm 0.03[49]$ & ${ }^{\mathrm{y}} 0.16 \pm 0.01[31]$ & & & & & & \\
\hline 1999 & ${ }^{\mathrm{cd}} 0.23 \pm 0.03$ [39] & ${ }^{\mathrm{y}} 0.17 \pm 0.01[32]$ & $* 8.0 \pm 4.9[48]$ & $14.6 \pm 8.4[16]$ & $0.85 \pm 0.09[260]$ & ${ }^{y_{0}} 0.90 \pm 0.07[187]$ & $* 38.7 \pm 11.0[511]$ & ${ }^{\mathrm{y}} 13.9 \pm 5.6[266]$ \\
\hline $\begin{array}{l}2000 \\
2001\end{array}$ & & & & & & & & \\
\hline 2002 & $e^{e} 017+001[397$ & $010+001[26$ & & & $086+0085817$ & $\mathrm{y}_{0} 00+0.07[187]$ & & \\
\hline
\end{tabular}

Note: in grey, pre-impoundment years. *: Statistical $(\alpha<0.05)$ difference from the pre-impoundment level.

y: Statistical $(\alpha<0.05)$ difference between reservoir and natural lake values by year.

Letters attributed to mercury levels in reservoir indicate the results of year to year multiple comparisons of means where the letter a is given to the highest value and where levels with different letters are significantly different $(\alpha<0.05)$. 
Table 4. Total mercury concentration ( \pm confidence interval[n]) at $400 \mathrm{~mm}$, fishing yields (CPUE $\pm \mathrm{SD}[\mathrm{n}])$, condition factor $\mathrm{K}(300-500 \mathrm{~mm}, \pm \mathrm{SD}[\mathrm{n}])$ and small specimen proportions $(<250 \mathrm{~mm}, \pm \mathrm{SD}[\mathrm{n}])$ for longnose sucker in the major La Grande reservoirs and the reference lakes.

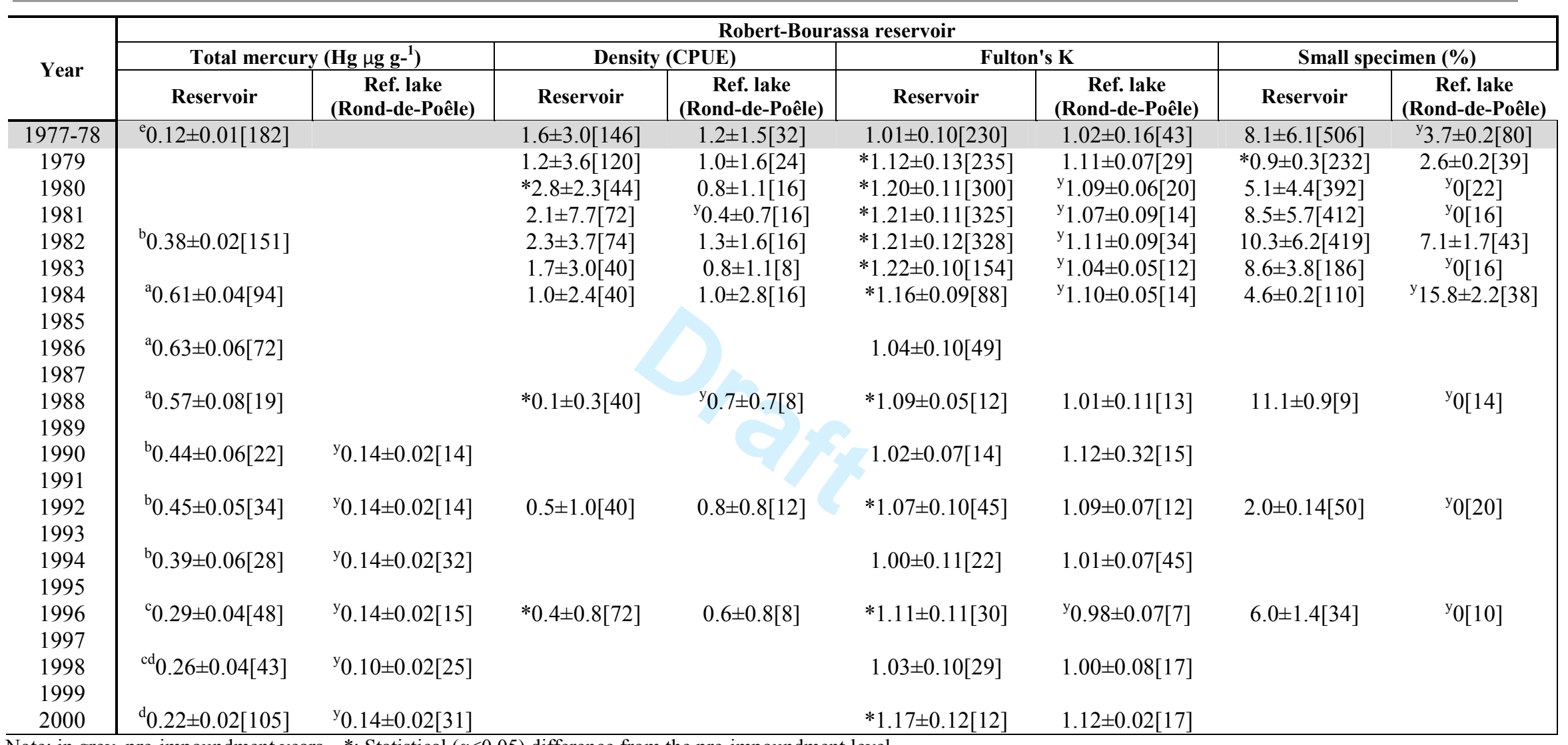

Note: in grey, pre-impoundment years. *: Statistical $(\alpha<0.05)$ difference from the pre-impoundment level.

y: Statistical $(\alpha<0.05)$ difference between reservoir and natural lake values by year.

Letters attributed to mercury levels in reservoir indicate the results of year to year multiple comparisons of means where the letter a is given to the highest value and where levels with different letters are significantly different $(\alpha<0.05)$. 
Table 4. (cont.) Total mercury concentration ( \pm confidence interval[n]) at $400 \mathrm{~mm}$, fishing yields (CPUE $\pm \mathrm{SD}[\mathrm{n}]$ ), condition factor $\mathrm{K}$ (300-500 mm, $\pm \mathrm{SD}[\mathrm{n}])$ and small specimen proportions $(<250 \mathrm{~mm}, \pm \mathrm{SD}[\mathrm{n}])$ for longnose sucker in the major La Grande reservoirs and the reference lakes.

\begin{tabular}{|c|c|c|c|c|c|c|c|c|}
\hline \multirow{3}{*}{ Year } & \multicolumn{8}{|c|}{ Opinaca reservoir } \\
\hline & \multicolumn{2}{|c|}{ Total mercury $\left(\mathrm{Hg} \mu \mathrm{g} \mathrm{g-}^{\mathbf{1}}\right)$} & \multicolumn{2}{|c|}{ Density (CPUE) } & \multicolumn{2}{|c|}{ Fulton's K } & \multicolumn{2}{|c|}{ Small specimen (\%) } \\
\hline & Reservoir & $\begin{array}{c}\text { Ref. lake } \\
\text { (Detcheverry) }\end{array}$ & Reservoir & $\begin{array}{c}\text { Ref. lake } \\
\text { (Detcheverry) }\end{array}$ & Reservoir & $\begin{array}{c}\text { Ref. lake } \\
\text { (Detcheverry) }\end{array}$ & Reservoir & $\begin{array}{c}\text { Ref. lake } \\
\text { (Detcheverry) }\end{array}$ \\
\hline 1978 & ${ }^{\mathrm{d}} 0.12 \pm 0.01[182]$ & & $0.4 \pm 0.8[68]$ & $0.2 \pm 0.3[16]$ & $1.05 \pm 0.11[50]$ & $1.08 \pm 0.06[6]$ & $6.2 \pm 1.9[65]$ & $12.5 \pm 0.9[8]$ \\
\hline 1979 & & & $0.8 \pm 2.3[68]$ & $0.1 \pm 0.2[16]$ & $1.06 \pm 0.07[84]$ & & $3.1 \pm 0.2[96]$ & ${ }^{\mathrm{y}} 42.9 \pm 1.3[7]$ \\
\hline 1980 & & & $* 1.6 \pm 2.1[60]$ & ${ }^{\mathrm{y}} 0.1 \pm 0.2[16]$ & $1.07 \pm 0.10[181]$ & & $2.5 \pm 0.2[203]$ & ${ }^{\mathrm{y}} 0[3]$ \\
\hline 1981 & & & $0.4 \pm 1.2[63]$ & $0.9 \pm 1.4[16]$ & $* 1.20 \pm 0.11[50]$ & ${ }^{\mathrm{y}} 1.09 \pm 0.07[14]$ & $3.6 \pm 0.2[56]$ & ${ }^{\mathrm{y}} 21.1 \pm 1.8[19]$ \\
\hline 1982 & & & $0.4 \pm 0.9[56]$ & $0.7 \pm 1.2[12]$ & $* 1.24 \pm 0.09[38]$ & ${ }^{\mathrm{y}} 1.01 \pm 0.09[13]$ & $* 0[59]$ & ${ }^{\mathrm{y}} 11.8 \pm 1.3[17]$ \\
\hline 1983 & & & $0.4 \pm 0.8[36]$ & $0.5 \pm 1.1[8]$ & $* 1.25 \pm 0.11[30]$ & ${ }^{\mathrm{y}} 1.10 \pm 0.07[5]$ & $2.7 \pm 0.2[37]$ & $12.5 \pm 0.9[8]$ \\
\hline 1984 & ${ }^{\mathrm{a}} 0.72 \pm 0.12[9]$ & & $0.3 \pm 0.4[32]$ & $0.9 \pm 2.3[16]$ & $* 1.24 \pm 0.12[11]$ & $1.15 \pm 0.09[6]$ & $* 0[24]$ & ${ }^{\mathrm{y}} 25.0 \pm 1.7[16]$ \\
\hline 1985 & & & & & & & & \\
\hline 1986 & ${ }^{\mathrm{ab}} 0.57 \pm 0.08[18]$ & & & & $* 1.12 \pm 0.09[18]$ & & & \\
\hline 1987 & & & & & & & & \\
\hline 1988 & & & $0.1 \pm 0.3[32]$ & $0.1 \pm 0.4[8]$ & $1.03 \pm 0.08[5]$ & & $* 0[8]$ & ${ }^{\mathrm{y}} 71.4 \pm 1.7[14]$ \\
\hline 1989 & & & & & & & & \\
\hline 1990 & & & & & $1.06 \pm 0.07[9]$ & & & \\
\hline 1991 & & & & & & & & \\
\hline 1992 & ${ }^{\mathrm{b}} 0.50 \pm 0.06[27]$ & & $0.6 \pm 1.8[40]$ & $0.1 \pm 0.2[12]$ & $1.09 \pm 0.08[37]$ & & $3.9 \pm 0.2[51]$ & ${ }^{\mathrm{y}} 60.0 \pm 2.2[20]$ \\
\hline 1993 & & & & & & & & \\
\hline 1994 & & & & & $1.12 \pm 0.10[6]$ & & & \\
\hline 1995 & & & & & & & & \\
\hline 1996 & ${ }^{\mathrm{c}} 0.33 \pm 0.05[34]$ & & $0.3 \pm 0.4[88]$ & $0.3 \pm 0.5[16]$ & $1.08 \pm 0.14[17]$ & & $* 0[30]$ & $0[10]$ \\
\hline 1997 & & & & & & & & \\
\hline 1998 & & & & & & & & \\
\hline 1999 & & & & & & & & \\
\hline 2000 & ${ }^{\mathrm{c}} 0.27 \pm 0.06[31]$ & & & & $* 1.12 \pm 0.08[24]$ & & & \\
\hline
\end{tabular}

Note: in grey, pre-impoundment years. *: Statistical $(\alpha<0.05)$ difference from the pre-impoundment level.

y: Statistical $(\alpha<0.05)$ difference between reservoir and natural lake values by year.

Letters attributed to mercury levels in reservoir indicate the results of year to year multiple comparisons of means where the letter a is given to the highest value and where levels with different letters are significantly different $(\alpha<0.05)$. 
Table 4. (cont.) Total mercury concentration ( \pm confidence interval[ $\mathrm{n}]$ ) at $400 \mathrm{~mm}$, fishing yields (CPUE $\pm \mathrm{SD}[\mathrm{n}]$ ), condition factor $\mathrm{K}$ (300-500 mm, $\pm \mathrm{SD}[\mathrm{n}])$ and small specimen proportions $(<250 \mathrm{~mm}, \pm \mathrm{SD}[\mathrm{n}])$ for longnose sucker in the major La Grande reservoirs and the reference lakes.

\begin{tabular}{|c|c|c|c|c|c|c|c|c|}
\hline \multirow{3}{*}{ Year } & \multicolumn{8}{|c|}{ Caniapiscau reservoir } \\
\hline & \multicolumn{2}{|c|}{ Total mercury $\left(\mathrm{Hg}_{\mu \mathrm{g}} \mathrm{g}_{-}{ }^{1}\right)$} & \multicolumn{2}{|c|}{ Density (CPUE) } & \multicolumn{2}{|c|}{ Fulton's K } & \multicolumn{2}{|c|}{ Small specimen (\%) } \\
\hline & Reservoir & $\begin{array}{l}\text { Ref. lake } \\
\text { (Hazeur) }\end{array}$ & Reservoir & $\begin{array}{l}\text { Ref. lake } \\
\text { (Hazeur) }\end{array}$ & Reservoir & $\begin{array}{l}\text { Ref. lake } \\
\text { (Hazeur) }\end{array}$ & Reservoir & $\begin{array}{l}\text { Ref. lake } \\
\text { (Hazeur) }\end{array}$ \\
\hline 1980 & ${ }^{\mathrm{f}} 0.13 \pm 0.01[246]$ & & $3.8 \pm 5.2[48]$ & & $1.04 \pm 0.09[165]$ & & $12.2 \pm 6.3[376]$ & \\
\hline 1981 & & & $4.8 \pm 5.7[48]$ & & $1.03 \pm 0.10[240]$ & ${ }^{\mathrm{y}} 0.90 \pm 0.08[25]$ & $22.6 \pm 9.0[461]$ & \\
\hline 1982 & & & $* 8.2 \pm 7.5[64]$ & ${ }^{\mathrm{y}} 0.6 \pm 1.0[16]$ & $* 1.08 \pm 0.10[377]$ & ${ }^{\mathrm{y}} 0.91 \pm 0.08[10]$ & $* 9.4 \pm 8.2[787]$ & ${ }^{\mathrm{y}} 85.0 \pm 6.6[20]$ \\
\hline 1983 & & & & & & & & \\
\hline 1984 & & & & & & & & \\
\hline 1985 & & & & & & & & \\
\hline 1986 & & & & & & & & \\
\hline 1987 & ${ }^{\mathrm{c}} 0.34 \pm 0.03[117]$ & ${ }^{\mathrm{y}} 0.11 \pm 0.01[32]$ & $4.8 \pm 4.5[40]$ & $3.1 \pm 4.1[12]$ & $* 1.20 \pm 0.17[220]$ & ${ }^{\mathrm{y}} 0.95 \pm 0.04[38]$ & $9.8 \pm 5.2[307]$ & ${ }^{\mathrm{y}} 84.3 \pm 2.6[51]$ \\
\hline 1988 & & & & & & & & \\
\hline 1989 & ${ }^{\mathrm{ab}} 0.45 \pm 0.04[77]$ & ${ }^{\mathrm{y}} 0.11 \pm 0.01[24]$ & & & $* 1.09 \pm 0.11[42]$ & & & \\
\hline 1990 & & & & & & & & \\
\hline 1991 & ${ }^{\mathrm{a}} 0.52 \pm 0.04[105]$ & ${ }^{\mathrm{y}} 0.10 \pm 0.02[22]$ & $4.3 \pm 6.6[24]$ & $4.8 \pm 2.4[8]$ & $1.04 \pm 0.09[132]$ & $1.03 \pm 0.06[11]$ & $15.9 \pm 6.1[276]$ & ${ }^{\mathrm{y}} 6.5 \pm 1.7[46]$ \\
\hline 1992 & & & & & & & & \\
\hline 1993 & ${ }^{\mathrm{a}} 0.49 \pm 0.04[120]$ & ${ }^{\mathrm{y}} 0.11 \pm 0.01[29]$ & $3.8 \pm 5.3[48]$ & $4.6 \pm 4.8[24]$ & $* 1.12 \pm 0.11[93]$ & $1.12 \pm 0.09[12]$ & $23.5 \pm 6.8[255]$ & ${ }^{\mathrm{y}} 34.5 \pm 5.0[110]$ \\
\hline 1994 & & & & & & & & \\
\hline 1995 & ${ }^{\mathrm{bc}} 0.39 \pm 0.04[122]$ & ${ }^{\mathrm{y}} 0.06 \pm 0.02[30]$ & $4.0 \pm 5.1[55]$ & $4.0 \pm 5.3[12]$ & $* 1.10 \pm 0.09[111]$ & $1.02 \pm 0.11[9]$ & $19.1 \pm 6.3[257]$ & ${ }^{\mathrm{y}} 58.9 \pm 3.7[56]$ \\
\hline 1996 & & & & & & & & \\
\hline 1997 & ${ }^{\mathrm{d}} 0.24 \pm 0.02[126]$ & ${ }^{\mathrm{y}} 0.08 \pm 0.02[31]$ & & & & & & \\
\hline 1998 & & & & & & & & \\
\hline 1999 & ${ }^{\mathrm{d}} 0.22 \pm 0.02[128]$ & ${ }^{\mathrm{y}} 0.08 \pm 0.02[32]$ & $4.0 \pm 3.3[48]$ & $3.6 \pm 3.8[16]$ & $* 1.12 \pm 0.09[146]$ & ${ }^{\mathrm{y}} 1.06 \pm 0.07[36]$ & $22.8 \pm 6.7[255]$ & ${ }^{\mathrm{y}} 15.8 \pm 2.8[57]$ \\
\hline 2000 & & & & & & & & \\
\hline 2001 & & & & & & & & \\
\hline 2002 & & & & & & & & \\
\hline 2003 & ${ }^{\mathrm{e}} 0.17 \pm 0.02[128]$ & ${ }^{\mathrm{y}} 0.10 \pm 0.01[32]$ & & & $* 1.08 \pm 0.09[59]$ & $1.05 \pm 0.098[40]$ & & \\
\hline
\end{tabular}

Note: in grey, pre-impoundment years. *: Statistical $(\alpha<0.05)$ difference from the pre-impoundment level.

y: Statistical $(\alpha<0.05)$ difference between reservoir and natural lake values by year.

Letters attributed to mercury levels in reservoir indicate the results of year to year multiple comparisons of means where the letter a is given to the highest value and where levels with different letters are significantly different $(\alpha<0.05)$. 
Table 5. Total mercury concentration ( \pm confidence interval $[\mathrm{n}])$ at $700 \mathrm{~mm}$, fishing yields (CPUE $\pm \mathrm{SD}[\mathrm{n}])$, condition factor $\mathrm{K}(500-700 \mathrm{~mm}, \pm \mathrm{SD}[\mathrm{n}])$ and small specimen proportions $(<350 \mathrm{~mm}, \pm \mathrm{SD}[\mathrm{n}])$ for northern pike in the major La Grande reservoirs and the reference lakes.

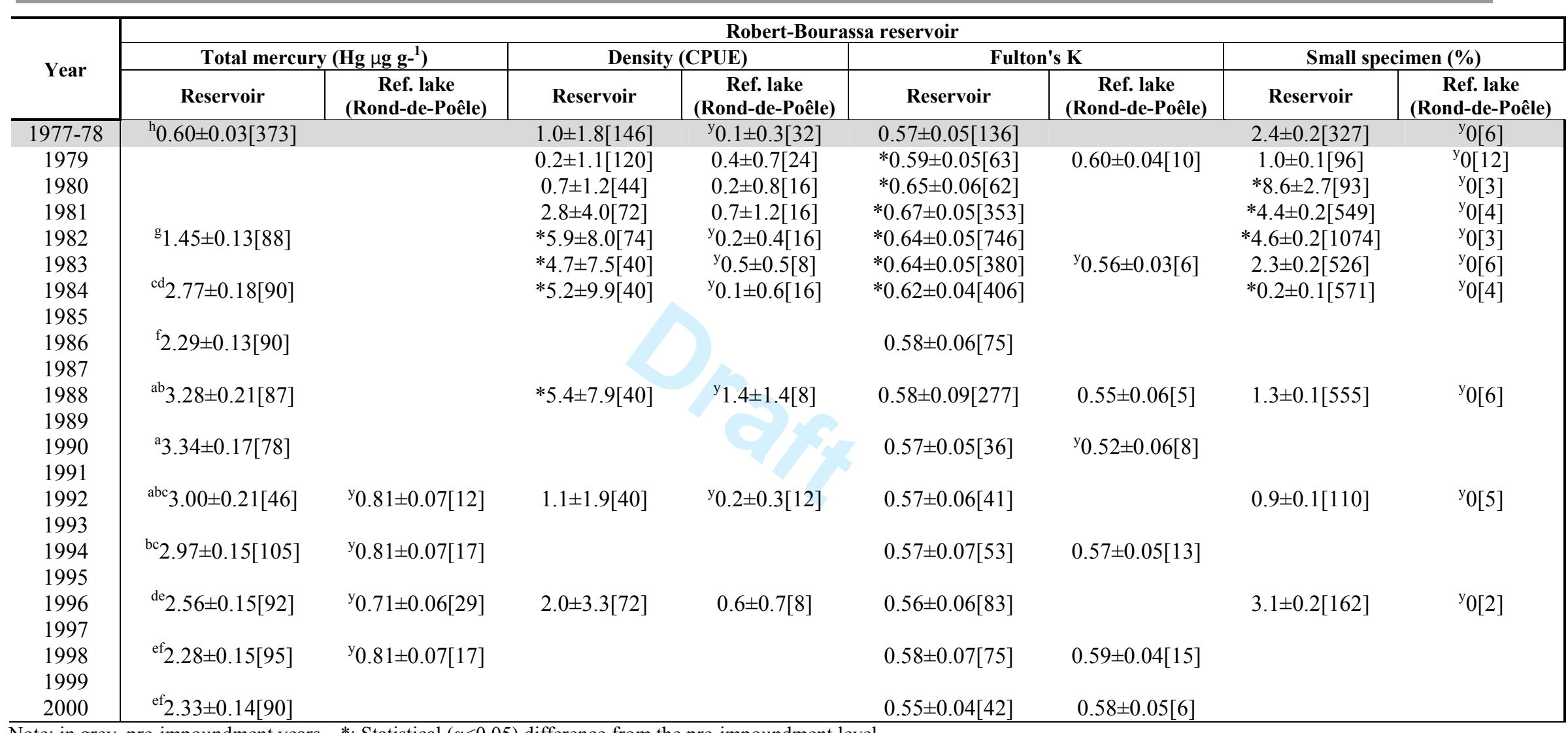

Note: in grey, pre-impoundment years. *: Statistical $(\alpha<0.05)$ difference from the pre-impoundment level.

y: Statistical $(\alpha<0.05)$ difference between reservoir and natural lake values by year.

Letters attributed to mercury levels in reservoir indicate the results of year to year multiple comparisons of means where the letter a is given to the highest value and where levels with different letters are significantly different $(\alpha<0.05)$. 
Table 5. (cont.) Total mercury concentration ( \pm confidence interval[n]) at $700 \mathrm{~mm}$, fishing yields $(\mathrm{CPUE} \pm \mathrm{SD}[\mathrm{n}])$, condition factor $\mathrm{K}(500-700 \mathrm{~mm}$, $\pm \mathrm{SD}[\mathrm{n}])$ and small specimen proportions $(<350 \mathrm{~mm}, \pm \mathrm{SD}[\mathrm{n}])$ for northern pike in the major La Grande reservoirs and the reference lakes.

\begin{tabular}{|c|c|c|c|c|c|c|c|c|}
\hline \multirow{3}{*}{ Year } & \multicolumn{8}{|c|}{ Opinaca reservoir } \\
\hline & \multicolumn{2}{|c|}{ Total mercury $\left(\mathrm{Hg} \mu \mathrm{g} \mathrm{g}^{-1}\right)$} & \multicolumn{2}{|c|}{ Density (CPUE) } & \multicolumn{2}{|c|}{ Fulton's K } & \multicolumn{2}{|c|}{ Small specimen (\%) } \\
\hline & Reservoir & $\begin{array}{c}\text { Ref. lake } \\
\text { (Detcheverry) }\end{array}$ & Reservoir & $\begin{array}{c}\text { Ref. lake } \\
\text { (Detcheverry) }\end{array}$ & Reservoir & $\begin{array}{c}\text { Ref. lake } \\
\text { (Detcheverry) }\end{array}$ & Reservoir & $\begin{array}{c}\text { Ref. lake } \\
\text { (Detcheverry) }\end{array}$ \\
\hline 1978 & ${ }^{\mathrm{e}} 0.60 \pm 0.03[373]$ & & $1.7 \pm 1.3[68]$ & $2.9 \pm 2.1[16]$ & $0.54 \pm 0.09[150]$ & $0.55 \pm 0.06[78]$ & $4.0 \pm 0.2[278]$ & ${ }^{\mathrm{y}} 0[112]$ \\
\hline 1979 & & & $1.3 \pm 1.7[68]$ & $2.1 \pm 2.8[16]$ & $0.56 \pm 0.05[112]$ & $0.55 \pm 0.04[50]$ & $4.5 \pm 0.2[154]$ & ${ }^{\mathrm{y}} 0[76]$ \\
\hline 1980 & & & $1.0 \pm 1.2[60]$ & ${ }^{\mathrm{y}} 2.6 \pm 1.8[16]$ & $0.56 \pm 0.04[58]$ & $0.54 \pm 0.05[51]$ & $2.4 \pm 0.2[127]$ & ${ }^{\mathrm{y}} 1.5 \pm 0.1[68]$ \\
\hline 1981 & & & $1.4 \pm 1.9[63]$ & $3.4 \pm 4.1[16]$ & $* 0.62 \pm 0.07[98]$ & ${ }^{\mathrm{y}} 0.54 \pm 0.05[76]$ & $* 20.9 \pm 5.9[211]$ & ${ }^{\mathrm{y}} 0[64]$ \\
\hline 1982 & & & $* 3.8 \pm 3.3[56]$ & $2.7 \pm 3.2[12]$ & $* 0.65 \pm 0.05[254]$ & ${ }^{\mathrm{y}} 0.56 \pm 0.05[70]$ & $* 9.0 \pm 6.8[564]$ & ${ }^{\mathrm{y}} 0[99]$ \\
\hline 1983 & & & $* 4.3 \pm 5.4[36]$ & $2.4 \pm 1.7[8]$ & $* 0.62 \pm 0.06[283]$ & ${ }^{\mathrm{y}} 0.57 \pm 0.04[58]$ & $4.0 \pm 0.2[446]$ & ${ }^{\mathrm{y}} 0[72]$ \\
\hline 1984 & ${ }^{\mathrm{bc}} 2.25 \pm 0.21[30]$ & ${ }^{y_{0}} 0.82 \pm 0.04[28]$ & $* 6.1 \pm 8.4[32]$ & $4.5 \pm 6.4[16]$ & $* 0.61 \pm 0.05[265]$ & ${ }^{\mathrm{y}} 0.56 \pm 0.05[57]$ & $* 0.8 \pm 0.1[488]$ & ${ }^{\mathrm{y}} 0[148]$ \\
\hline 1985 & & & & & & & & \\
\hline 1986 & ${ }^{\mathrm{cd}} 1.88 \pm 0.25[28]$ & ${ }^{y_{0}} 0.82 \pm 0.04[14]$ & & & $* 0.58 \pm 0.06[57]$ & $0.59 \pm 0.05[6]$ & & \\
\hline 1987 & & & & & & & & \\
\hline 1988 & ${ }^{\mathrm{bc}} 2.13 \pm 0.21[29]$ & ${ }^{y_{0}} 0.82 \pm 0.04[26]$ & $* 6.4 \pm 7.5[32]$ & $2.4 \pm 1.7[8]$ & $0.57 \pm 0.09[273]$ & $0.57 \pm 0.06[45]$ & $1.8 \pm 0.1[511]$ & ${ }^{\mathrm{y}} 1.1 \pm 0.1[94]$ \\
\hline 1989 & & & & & & & & \\
\hline 1990 & a $2.77 \pm 0.20[46]$ & ${ }^{y_{0}} 0.82 \pm 0.04[17]$ & & & $0.54 \pm 0.06[87]$ & $0.56 \pm 0.04[8]$ & & \\
\hline 1991 & & & & & & & & \\
\hline 1992 & ${ }^{\mathrm{a}} 2.69 \pm 0.23[54]$ & ${ }^{y_{0}} 0.69 \pm 0.10[22]$ & $2.2 \pm 1.9[40]$ & $2.8 \pm 1.5[12]$ & $0.57 \pm 0.06[97]$ & ${ }^{\mathrm{y}} 0.60 \pm 0.03[36]$ & $3.7 \pm 0.2[214]$ & ${ }^{\mathrm{y}} 0[62]$ \\
\hline 1993 & & & & & & & & \\
\hline 1994 & ${ }^{\mathrm{ab}} 2.47 \pm 0.15[65]$ & ${ }^{\mathrm{y}} 0.63 \pm 0.08[35]$ & & & $0.55 \pm 0.07[149]$ & $0.57 \pm 0.06[51]$ & & \\
\hline 1995 & & & & & & & & \\
\hline 1996 & ${ }^{\mathrm{b}} 2.30 \pm 0.15[62]$ & ${ }^{y_{0}} 0.82 \pm 0.04[31]$ & $* 3.4 \pm 3.4[88]$ & $3.8 \pm 3.4[16]$ & $0.53 \pm 0.05[109]$ & $0.54 \pm 0.05[29]$ & $3.8 \pm 0.2[338]$ & ${ }^{\mathrm{y}} 0[56]$ \\
\hline 1997 & & & & & & & & \\
\hline 1998 & & $0.82 \pm 0.04[31]$ & & & & $0.57 \pm 0.05[28]$ & & \\
\hline 1999 & & & & & & & & \\
\hline 2000 & ${ }^{\mathrm{d}} 1.53 \pm 0.14[63]$ & ${ }^{\mathrm{y}_{0}} 0.82 \pm 0.04[30]$ & & & $0.55 \pm 0.06[46]$ & $0.57 \pm 0.03[12]$ & & \\
\hline
\end{tabular}

Note: in grey, pre-impoundment years. $*$ : Statistical $(\alpha<0.05)$ difference from the pre-impoundment level.

y: Statistical $(\alpha<0.05)$ difference between reservoir and natural lake values by year.

Letters attributed to mercury levels in reservoir indicate the results of year to year multiple comparisons of means where the letter a is given to the highest value and where levels with different letters are significantly different $(\alpha<0.05)$. 
Table 5. (cont.) Total mercury concentration ( \pm confidence interval[ $\mathrm{n}])$ at $700 \mathrm{~mm}$, fishing yields $(\mathrm{CPUE} \pm \mathrm{SD}[\mathrm{n}])$, condition factor $\mathrm{K}(500-700 \mathrm{~mm}$, $\pm \mathrm{SD}[\mathrm{n}])$ and small specimen proportions $(<350 \mathrm{~mm}, \pm \mathrm{SD}[\mathrm{n}])$ for northern pike in the major La Grande reservoirs and the reference lakes.

\begin{tabular}{|c|c|c|c|c|c|c|c|c|}
\hline \multirow{3}{*}{ Year } & \multicolumn{8}{|c|}{ Caniapiscau reservoir } \\
\hline & \multicolumn{2}{|c|}{ 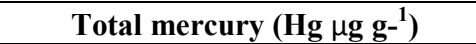 } & \multicolumn{2}{|c|}{ Density (CPUE) } & \multicolumn{2}{|c|}{ Fulton's K } & \multicolumn{2}{|c|}{ Small specimen (\%) } \\
\hline & Reservoir & $\begin{array}{l}\text { Ref. lake } \\
\text { (Hazeur) }\end{array}$ & Reservoir & $\begin{array}{l}\text { Ref. lake } \\
\text { (Hazeur) }\end{array}$ & Reservoir & $\begin{array}{l}\text { Ref. lake } \\
\text { (Hazeur) }\end{array}$ & Reservoir & $\begin{array}{l}\text { Ref. lake } \\
\text { (Hazeur) }\end{array}$ \\
\hline $\begin{array}{l}1980 \\
1981\end{array}$ & ${ }^{\mathrm{e}} 0.59 \pm 0.06[120]$ & & $\begin{array}{l}0.2 \pm 0.8[48] \\
0.5 \pm 1.3[48]\end{array}$ & & $0.60 \pm 0.04[7]$ & $0.52 \pm 0.07[7]$ & $\begin{array}{l}0[17] \\
0[46]\end{array}$ & \\
\hline $\begin{array}{l}1982 \\
1983 \\
1984 \\
1985 \\
1986\end{array}$ & & & $1.2 \pm 1.2[64]$ & & $0.64 \pm 0.05[40]$ & $0.67 \pm 0.05[10]$ & $* 0.9 \pm 0.1[115]$ & \\
\hline $\begin{array}{l}1987 \\
1988\end{array}$ & ${ }^{\mathrm{d}} 0.79 \pm 0.12[55]$ & & $* 4.7 \pm 6.8[40]$ & & $0.62 \pm 0.08[222]$ & & $* 0.7 \pm 0.1[301]$ & \\
\hline $\begin{array}{l}1989 \\
1990\end{array}$ & ${ }^{\mathrm{c}} 1.25 \pm 0.15[41]$ & & & & $0.60 \pm 0.04[43]$ & & & \\
\hline $\begin{array}{l}1991 \\
1992\end{array}$ & ${ }^{\mathrm{abc}} 1.57 \pm 0.22[16]$ & & $0.7 \pm 1.0[24]$ & & $0.60 \pm 0.04[20]$ & & $0[44]$ & \\
\hline $\begin{array}{l}1993 \\
1994\end{array}$ & ${ }^{\mathrm{a}} 1.86 \pm 0.16[39]$ & & $1.0 \pm 2.0[48]$ & & $0.61 \pm 0.05[49]$ & & $0[66]$ & \\
\hline $\begin{array}{l}1995 \\
1996\end{array}$ & ${ }^{\mathrm{ab}} 1.65 \pm 0.16[34]$ & & $* 1.9 \pm 2.4[55]$ & ${ }^{\mathrm{y}} 0.3 \pm 0.5[16]$ & $0.59 \pm 0.06[36]$ & & $* 0.9 \pm 0.1[115]$ & ${ }^{\mathrm{y}} 0[5]$ \\
\hline $\begin{array}{l}1997 \\
1998\end{array}$ & ${ }^{\mathrm{bc}} 1.49 \pm 0.11[64]$ & & & & $0.61 \pm 0.06[46]$ & & & \\
\hline $\begin{array}{l}1999 \\
2000 \\
2001 \\
2002\end{array}$ & ${ }^{\mathrm{bc}} 1.51 \pm 0.12[59]$ & & $* 2.1 \pm 1.4[48]$ & ${ }^{\mathrm{y}} 0.6 \pm 1.0[16]$ & $0.60 \pm 0.05[67]$ & & $* 0.8 \pm 0.1[133]$ & ${ }^{\mathrm{y}} 0[10]$ \\
\hline 2003 & ${ }^{\mathrm{c}} 1.30 \pm 0.11[57]$ & & & & $0.58 \pm 0.05[46]$ & & & \\
\hline
\end{tabular}

Note: in grey, pre-impoundment years. *: Statistical $(\alpha<0.05)$ difference from the pre-impoundment level.

y: Statistical $(\alpha<0.05)$ difference between reservoir and natural lake values by year.

Letters attributed to mercury levels in reservoir indicate the results of year to year multiple comparisons of means where the letter a is given to the highest value and where levels with different letters are significantly different $(\alpha<0.05)$. 
Table 6. Total mercury concentration ( \pm confidence interval $[\mathrm{n}])$ at $400 \mathrm{~mm}$, fishing yields $(\mathrm{CPUE} \pm \mathrm{SD}[\mathrm{n}])$, condition factor $\mathrm{K}(400-600 \mathrm{~mm}, \pm \mathrm{SD}[\mathrm{n}])$ and small specimen proportions $(<250 \mathrm{~mm}, \pm \mathrm{SD}[\mathrm{n}])$ for walleye in the major La Grande reservoirs and the reference lakes.

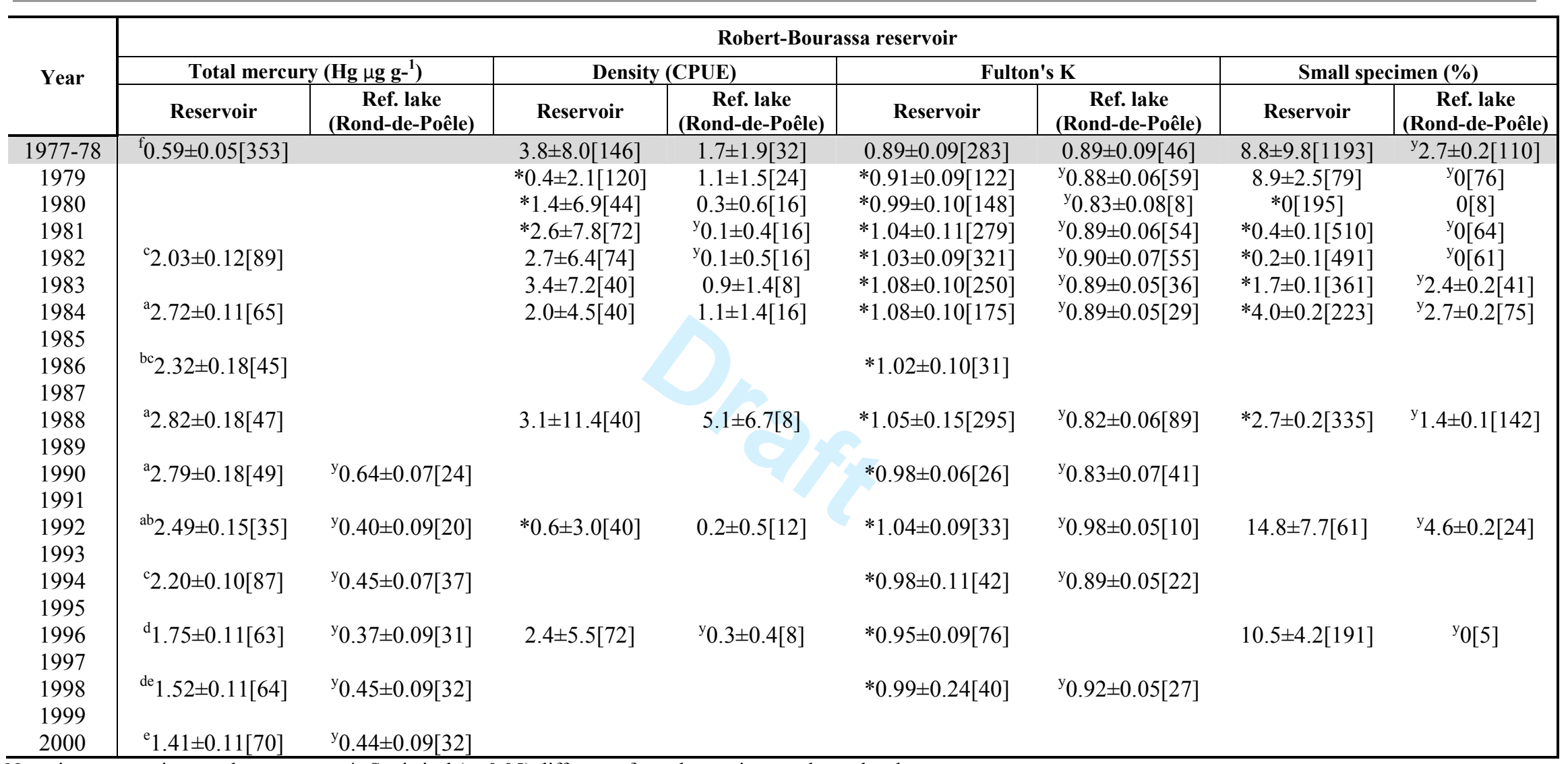

Note: in grey, pre-impoundment years. *: Statistical $(\alpha<0.05)$ difference from the pre-impoundment level.

y: Statistical $(\alpha<0.05)$ difference between reservoir and natural lake values by year.

Letters attributed to mercury levels in reservoir indicate the results of year to year multiple comparisons of means where the letter a is given to the highest value and where levels with different letters are significantly different $(\alpha<0.05)$. 
Table 6. (cont.) Total mercury concentration ( \pm confidence interval[n]) at $400 \mathrm{~mm}$, fishing yields $(\mathrm{CPUE} \pm \mathrm{SD}[\mathrm{n}])$, condition factor K (400-600 mm, $\pm \mathrm{SD}[\mathrm{n}])$ and small specimen proportions $(<250 \mathrm{~mm}, \pm \mathrm{SD}[\mathrm{n}])$ for walleye in the major La Grande reservoirs and the reference lakes.

\begin{tabular}{|c|c|c|c|c|c|c|c|c|}
\hline \multirow{3}{*}{ Year } & \multicolumn{8}{|c|}{ Opinaca reservoir } \\
\hline & \multicolumn{2}{|c|}{ Total mercury $\left(\mathrm{Hg} \mu \mathrm{gg} \mathbf{-}^{1}\right)$} & \multicolumn{2}{|c|}{ Density (CPUE) } & \multicolumn{2}{|c|}{ Fulton's K } & \multicolumn{2}{|c|}{ Small specimen (\%) } \\
\hline & Reservoir & $\begin{array}{c}\text { Ref. lake } \\
\text { (Detcheverry) }\end{array}$ & Reservoir & $\begin{array}{c}\text { Ref. lake } \\
\text { (Detcheverry) }\end{array}$ & Reservoir & $\begin{array}{c}\text { Ref. lake } \\
\text { (Detcheverry) }\end{array}$ & Reservoir & $\begin{array}{c}\text { Ref. lake } \\
\text { (Detcheverry) }\end{array}$ \\
\hline 1978 & $\mathrm{~h}_{0.59 \pm 0.05[353]}$ & & $5.1 \pm 8.5[68]$ & $6.1 \pm 5.2[16]$ & $0.86 \pm 0.09[468]$ & ${ }^{\mathrm{y}} 0.88 \pm 0.08[102]$ & $4.6 \pm 0.2[835]$ & ${ }^{\mathrm{y}} 19.7 \pm 4.8[147]$ \\
\hline 1979 & & & $4.8 \pm 7.6[68]$ & $3.0 \pm 2.4[16]$ & $0.86 \pm 0.08[373]$ & ${ }^{\mathrm{y}} 0.89 \pm 0.08[51]$ & $1.4 \pm 0.1[557]$ & ${ }^{\mathrm{y}} 18.4 \pm 3.8[98]$ \\
\hline 1980 & & & $5.6 \pm 7.8[60]$ & $2.4 \pm 1.5[16]$ & $0.87 \pm 0.08[575]$ & ${ }^{\mathrm{y}} 0.91 \pm 0.07[32]$ & $* 0.4 \pm 0.1[739]$ & ${ }^{\mathrm{y}} 6.5 \pm 1.9[62]$ \\
\hline 1981 & $\operatorname{defg}_{1.01 \pm 0.15[30]}$ & & $* 1.8 \pm 3.3[63]$ & ${ }^{\mathrm{y}} 9.8 \pm 7.2[16]$ & $* 0.95 \pm 0.08[217]$ & ${ }^{\mathrm{y}} 0.89 \pm 0.07[132]$ & $0.4 \pm 0.1[268]$ & $\mathrm{y}_{5} 5.7 \pm 3.3[200]$ \\
\hline 1982 & & & $* 1.6 \pm 2.4[56]$ & $3.9 \pm 3.1[12]$ & $* 0.99 \pm 0.09[204]$ & $\mathrm{y}_{0.89} \pm 0.07[47]$ & $1.3 \pm 0.2[237]$ & ${ }^{\mathrm{y}} 2.7 \pm 0.2[112]$ \\
\hline 1983 & & & $* 1.3 \pm 2.8[36]$ & ${ }^{\mathrm{y}} 8.9 \pm 6.6[8]$ & $* 0.98 \pm 0.11[115]$ & ${ }^{\mathrm{y}} 0.94 \pm 0.11[54]$ & $6.7 \pm 2.9[134]$ & $6.5 \pm 2.9[138]$ \\
\hline 1984 & ab $1.94 \pm 0.17[30]$ & ${ }^{\mathrm{y}} 0.68 \pm 0.03[30]$ & $* 0.8 \pm 1.4[32]$ & ${ }^{y_{9}} 9.3 \pm 10.3[16]$ & $* 1.07 \pm 0.10[48]$ & ${ }^{\mathrm{y}} 0.92 \pm 0.07[76]$ & $7.0 \pm 1.9[57]$ & ${ }^{\mathrm{y}} 4.1 \pm 0.2[244]$ \\
\hline 1985 & & & & & & & & \\
\hline 1986 & $\mathrm{ab}_{1.74 \pm 0.27[9]}$ & ${ }^{\mathrm{y}} 0.58 \pm 0.03[30]$ & & & $* 0.95 \pm 0.12[39]$ & ${ }^{\mathrm{y}} 0.83 \pm 0.14[14]$ & & \\
\hline 1987 & & & & & & & & \\
\hline 1988 & ${ }^{\mathrm{ab}} 1.99 \pm 0.21[18]$ & ${ }^{\mathrm{y}} 0.60 \pm 0.03[23]$ & $* 1.1 \pm 1.8[32]$ & ${ }^{\mathrm{y}} 10.5 \pm 9.2[8]$ & $* 1.08 \pm 0.09[38]$ & ${ }^{\mathrm{y}} 0.89 \pm 0.09[119]$ & $1.1 \pm 0.1[88]$ & ${ }^{\mathrm{y}} 2.4 \pm 0.2[255]$ \\
\hline 1989 & & & & & & & & \\
\hline 1990 & a2 $2.07 \pm 0.19[23]$ & ${ }^{\mathrm{y}} 0.57 \pm 0.03[28]$ & & & $* 0.97 \pm 0.16[25]$ & ${ }^{\mathrm{y}} 0.88 \pm 0.04[10]$ & & \\
\hline 1991 & & & & & & & & \\
\hline 1992 & ${ }^{\mathrm{ab}} 1.88 \pm 0.12[53]$ & ${ }^{\mathrm{y}} 0.57 \pm 0.03[30]$ & $3.4 \pm 3.5[40]$ & ${ }^{\mathrm{y}} 7.1 \pm 3.4[12]$ & $* 1.02 \pm 0.11[199]$ & ${ }^{\mathrm{y}} 0.95 \pm 0.07[90]$ & $3.9 \pm 0.2[330]$ & ${ }^{\mathrm{y}} 12.5 \pm 3.9[136]$ \\
\hline 1993 & & & & & & & & \\
\hline 1994 & ${ }^{\mathrm{b}} 1.65 \pm 0.18[32]$ & ${ }^{\mathrm{y}} 0.57 \pm 0.03[41]$ & & & $* 0.95 \pm 0.11[99]$ & ${ }^{\mathrm{y}} 0.86 \pm 0.07[107]$ & & \\
\hline 1995 & & & & & & & & \\
\hline 1996 & ${ }^{\mathrm{cd}} 1.28 \pm 0.15[67]$ & ${ }^{\mathrm{y}} 0.58 \pm 0.03[31]$ & $3.9 \pm 4.2[88]$ & $5.2 \pm 3.1[16]$ & $* 0.95 \pm 0.08[146]$ & ${ }^{\mathrm{y}} 0.86 \pm 0.06[41]$ & $* 11.4 \pm 6.2[386]$ & ${ }^{\mathrm{y}} 9.5 \pm 2.7[84]$ \\
\hline 1997 & & & & & & & & \\
\hline 1998 & & $0.58 \pm 0.03[32]$ & & & & $0.85 \pm 0.06[24]$ & & \\
\hline 1999 & & & & & & & & \\
\hline 2000 & ${ }^{\mathrm{g}} 0.76 \pm 0.12[61]$ & ${ }^{\mathrm{y}} 0.57 \pm 0.03[32]$ & & & $* 0.92 \pm 0.06[66]$ & $0.93 \pm 0.08[14]$ & & \\
\hline
\end{tabular}

Note: in grey, pre-impoundment years. *: Statistical $(\alpha<0.05)$ difference from the pre-impoundment level.

y: Statistical $(\alpha<0.05)$ difference between reservoir and natural lake values by year.

Letters attributed to mercury levels in reservoir indicate the results of year to year multiple comparisons of means where the letter a is given to the highest value and where levels with different letters are significantly different $(\alpha<0.05)$. 
Table 7. Total mercury concentration ( \pm confidence interval[n]) at $600 \mathrm{~mm}$, fishing yields $(\mathrm{CPUE} \pm \mathrm{SD}[\mathrm{n}])$, condition factor $\mathrm{K}(600-800 \mathrm{~mm}, \pm \mathrm{SD}[\mathrm{n}])$ and small specimen proportions $(<600 \mathrm{~mm}, \pm \mathrm{SD}[\mathrm{n}])$ for lake trout in the major La Grande reservoirs and the reference lakes.

\begin{tabular}{|c|c|c|c|c|c|c|c|c|}
\hline \multirow{3}{*}{ Year } & \multicolumn{8}{|c|}{ Caniapiscau reservoir } \\
\hline & \multicolumn{2}{|c|}{ Total mercury (Hg $\left.\mu \mathrm{g} \mathrm{g-}-^{1}\right)$} & \multicolumn{2}{|c|}{ Density (CPUE) } & \multicolumn{2}{|c|}{ Fulton's K } & \multicolumn{2}{|c|}{ Small specimen (\%) } \\
\hline & Reservoir & $\begin{array}{l}\text { Ref. lake } \\
\text { (Hazeur) }\end{array}$ & Reservoir & $\begin{array}{l}\text { Ref. lake } \\
\text { (Hazeur) }\end{array}$ & Reservoir & $\begin{array}{l}\text { Ref. lake } \\
\text { (Hazeur) }\end{array}$ & Reservoir & $\begin{array}{l}\text { Ref. lake } \\
\text { (Hazeur) }\end{array}$ \\
\hline 1980 & ${ }^{\mathrm{c}} 0.72 \pm 0.04[254]$ & & $2.9 \pm 2.2[48]$ & & $0.82 \pm 0.11[132]$ & & $31.2 \pm 7.9[288]$ & \\
\hline 1981 & & & $2.5 \pm 1.4[48]$ & & $0.82 \pm 0.08[177]$ & & $48.3 \pm 7.7[240]$ & \\
\hline 1982 & & & $* 1.5 \pm 1.1[64]$ & ${ }^{\mathrm{y}} 6.9 \pm 7.5[16]$ & $0.83 \pm 0.08[90]$ & $0.83 \pm 0.11[45]$ & $45.8 \pm 6.0[144]$ & ${ }^{\mathrm{y}} 61.9 \pm 5.6[134]$ \\
\hline 1983 & & & & & & & & \\
\hline 1984 & & & & & & & & \\
\hline 1985 & & & & & & & & \\
\hline 1986 & & & & & & & & \\
\hline 1987 & ${ }^{\mathrm{c}} 0.82 \pm 0.09[54]$ & $0.75 \pm 0.04[31]$ & $* 1.2 \pm 1.4[40]$ & ${ }^{y_{3}} 3.4 \pm 2.1[12]$ & $* 0.96 \pm 0.19[44]$ & $0.87 \pm 0.05[13]$ & $27.0 \pm 5.9[178]$ & $\mathrm{y}_{73.7 \pm 3.3[57]}$ \\
\hline 1988 & & & & & & & & \\
\hline 1989 & ${ }^{\mathrm{ab}} 1.56 \pm 0.23[44]$ & ${ }^{\mathrm{y}} 0.97 \pm 0.17[19]$ & & & $* 0.95 \pm 0.13[34]$ & ${ }^{\mathrm{y}} 0.78 \pm 0.02[6]$ & & \\
\hline 1990 & & & & & & & & \\
\hline 1991 & ${ }^{\mathrm{a}} 1.85 \pm 0.37[26]$ & ${ }^{\mathrm{y}} 0.75 \pm 0.04[19]$ & $* 0.6 \pm 1.1[24]$ & ${ }^{\mathrm{y}} 4.8 \pm 2.3[8]$ & $0.84 \pm 0.20[22]$ & $0.78 \pm 0.08[16]$ & $* 10.8 \pm 1.9[37]$ & ${ }^{\mathrm{y}} 73.6 \pm 3.2[53]$ \\
\hline 1992 & & & & & & & & \\
\hline 1993 & ${ }^{\mathrm{a}} 1.79 \pm 0.28[33]$ & ${ }^{\mathrm{y}} 0.75 \pm 0.04[28]$ & $* 0.6 \pm 0.9[48]$ & $\mathrm{y}_{3.0 \pm 1.6[24]}$ & $* 1.02 \pm 0.15[26]$ & ${ }^{\mathrm{y}} 0.84 \pm 0.10[6]$ & $* 2.9 \pm 0.2[35]$ & ${ }^{\mathrm{y}} 83.9 \pm 2.7[55]$ \\
\hline 1994 & & & & & & & & \\
\hline 1995 & ${ }^{\mathrm{ab}} 1.58 \pm 0.20[40]$ & ${ }^{\mathrm{y}} 0.75 \pm 0.04[22]$ & $* 0.7 \pm 1.3[55]$ & $2.2 \pm 2.5[12]$ & $* 1.06 \pm 0.16[19]$ & ${ }^{\mathrm{y}} 0.88 \pm 0.09[8]$ & $* 4.8 \pm 0.2[42]$ & ${ }^{\mathrm{y}} 77.1 \pm 2.2[27]$ \\
\hline 1996 & & & & & & & & \\
\hline 1997 & ${ }^{a b} 1.55 \pm 0.21[37]$ & ${ }^{\mathrm{y}} 0.75 \pm 0.04[28]$ & & & $* 1.14 \pm 0.18[37]$ & ${ }^{\mathrm{y}} 0.93 \pm 0.07[13]$ & & \\
\hline 1998 & & & & & & & & \\
\hline 1999 & ${ }^{\mathrm{a}} 1.76 \pm 0.24[38]$ & ${ }^{\mathrm{y}} 0.76 \pm 0.07[32]$ & $* 1.7 \pm 2.2[48]$ & ${ }^{\mathrm{y}} 4.1 \pm 2.1[16]$ & $* 1.03 \pm 0.11[49]$ & ${ }^{\mathrm{y}} 0.86 \pm 0.08[26]$ & $* 3.7 \pm 0.2[109]$ & $\mathrm{y}_{59.1 \pm 4.0[66]}$ \\
\hline 2000 & & & & & & & & \\
\hline 2001 & & & & & & & & \\
\hline 2002 & & & & & & & & \\
\hline 2003 & ${ }^{\mathrm{b}} 1.30 \pm 0.22[22]$ & ${ }^{\mathrm{y}} 0.75 \pm 0.04[13]$ & & & $* 0.97 \pm 0.14[28]$ & & & \\
\hline
\end{tabular}

https://mc06.manuscriptcentral.com/cjfas-pubs 
Fig. 1 La Grande hydroelectric complex

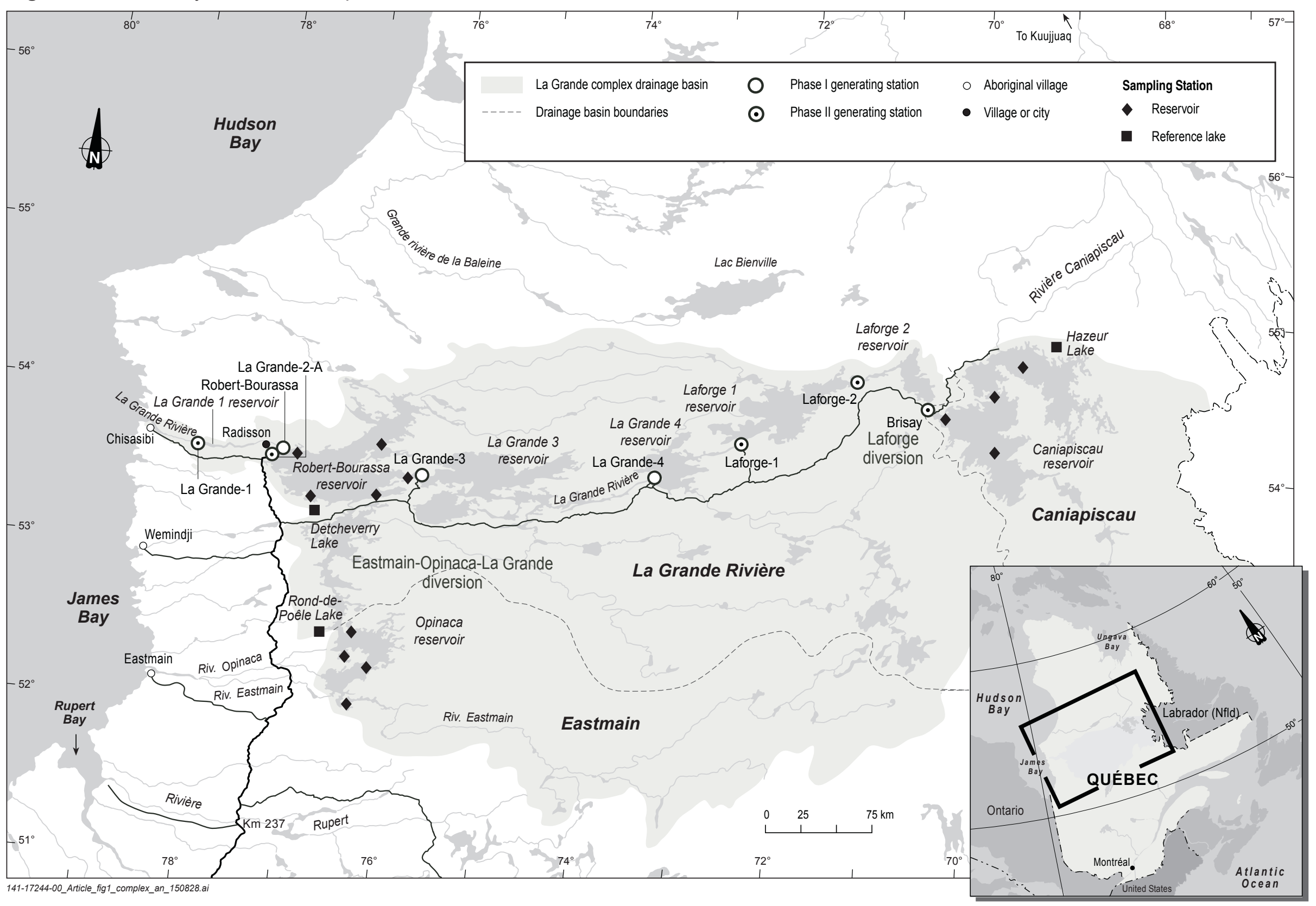


Fig. 2 Temporal evolution of mean total mercury levels (wet weight) at standardized length of major fish species caught in the natural lakes of the La Grande complex.

a) Longnose sucker $(400 \mathrm{~mm})$ Hazeur Lake

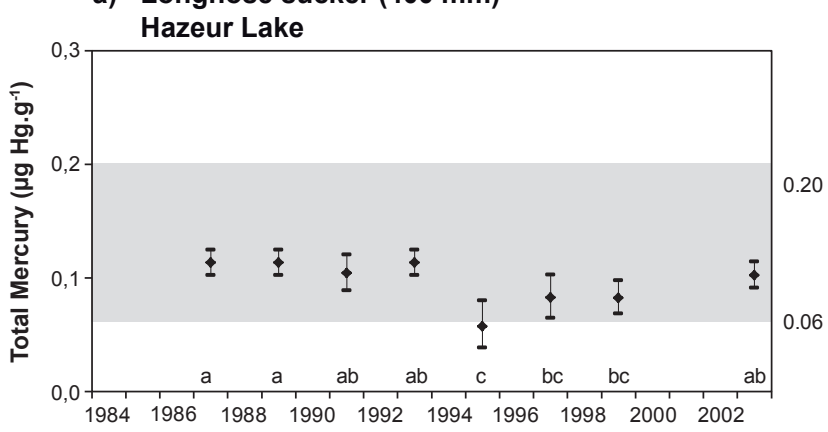

Year

c) Northern Pike $(700 \mathrm{~mm})$ Rond-de-Poêle Lake

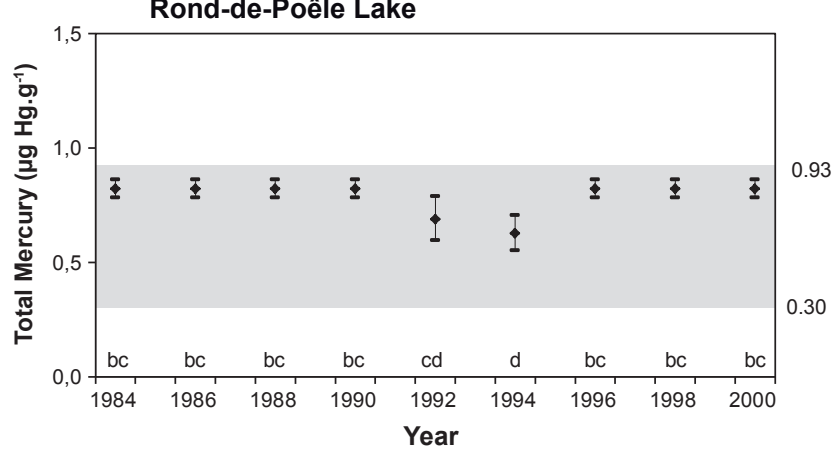

e) Lake Trout $(600 \mathrm{~mm})$ Hazeur Lake

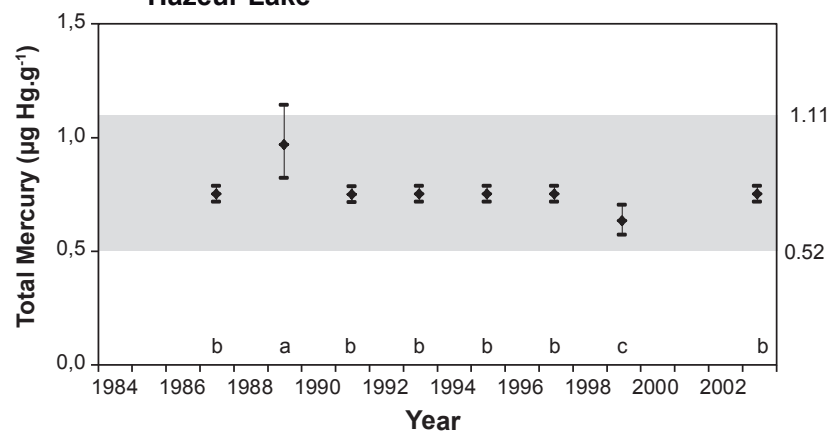

b) Lake Whitefish $(400 \mathrm{~mm})$

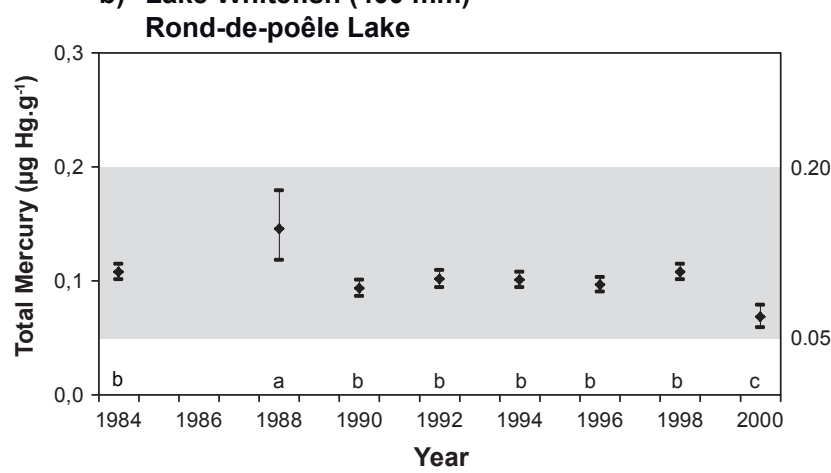

d) Walleye $(400 \mathrm{~mm})$

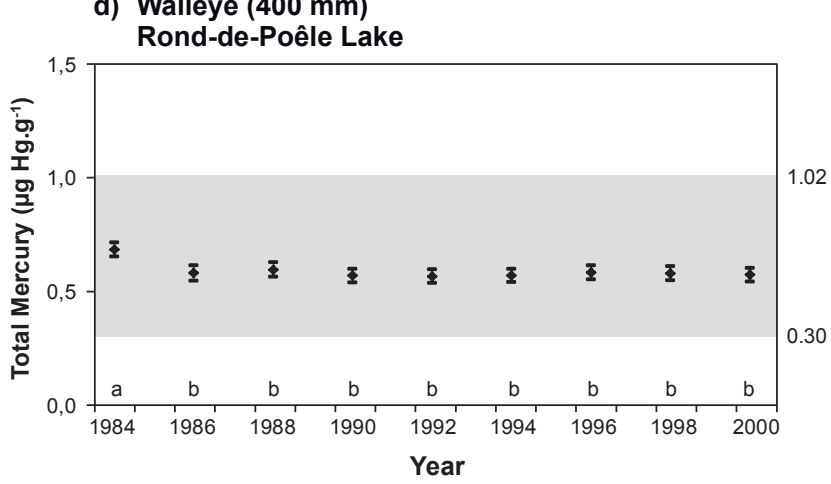

Notes: Vertical bars represent confidence intervals $(\alpha<0.05)$ of average means. Letters attributed to mercury levels in lake indicate the results of year to year multiple comparisons of means where the letter a is given to highest value and where levels with different letters are significantly different $(\alpha<0.05)$.

Range of mean levels measured under natural conditions for a standardized length. 
Fig. 3 Temporal evolution of mean total mercury (wet weight) levels and of Fulton's fish condition factor (K) for the major species in three reservoirs of the La Grande complex.

\section{a) Lake whitefish}
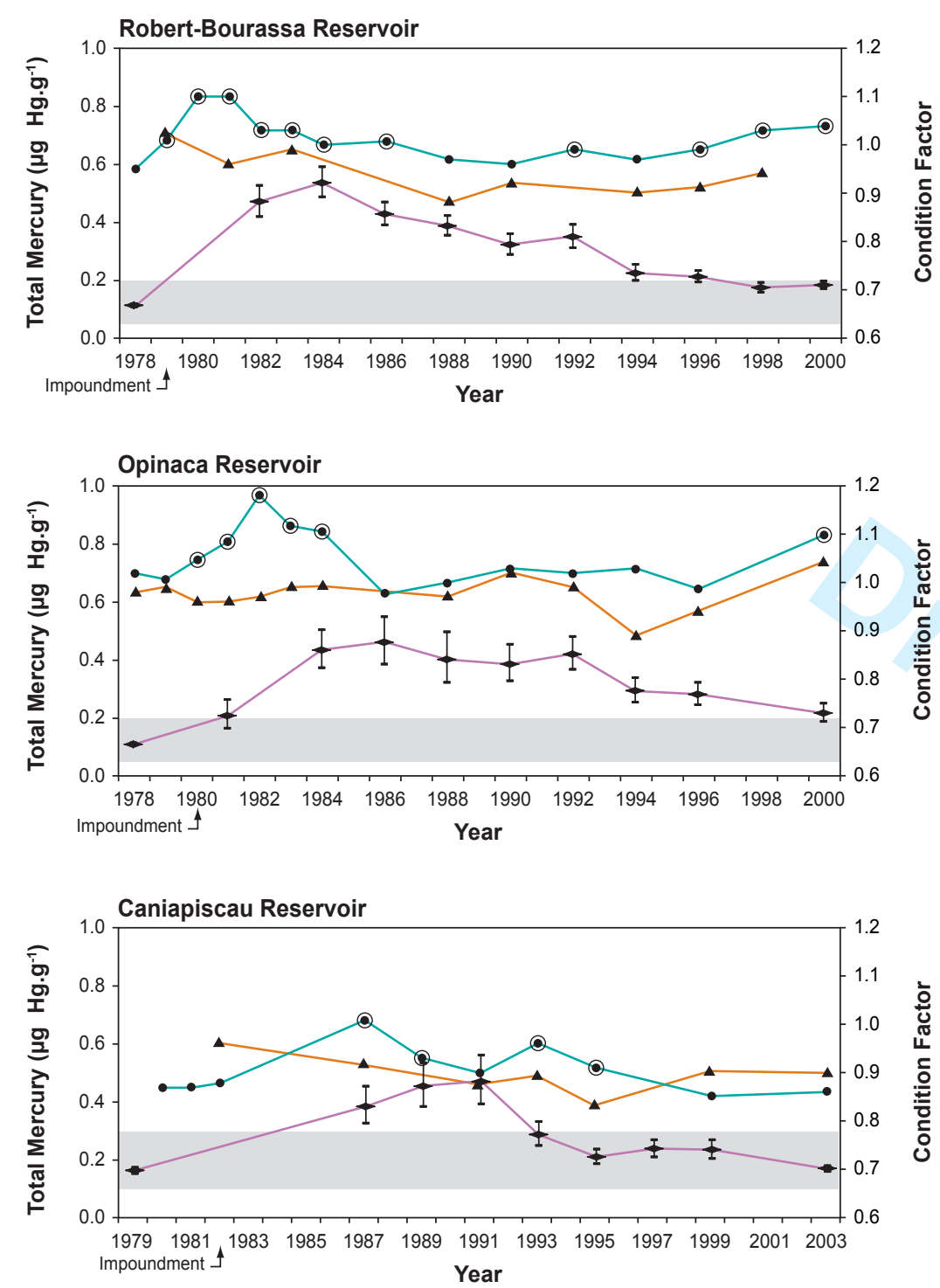

b) Longnose sucker
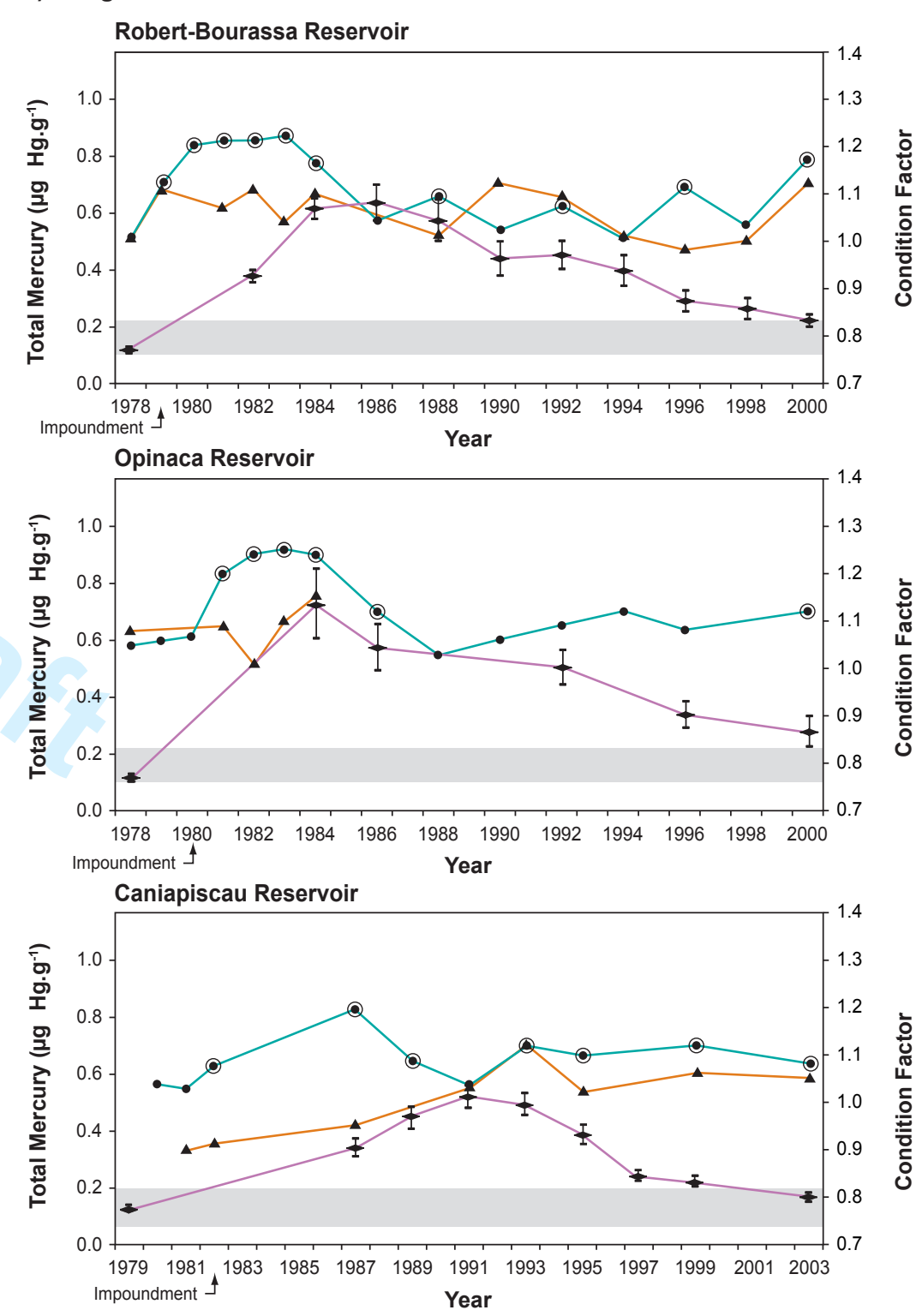

\footnotetext{
- Reservoir condition factor (K) Condition factor for length intervals

$\begin{array}{ll}\text { - Reservoir condition factor }(K) & \text { Condition factor for length intervals } \\ \text { - Ref. lake condition factor } & (\mathrm{a} \text { and } b=300-500 \mathrm{~mm}, \mathrm{c}=500-700 \mathrm{~mm}\end{array}$

- Statistical difference with pre-impoundment $(\alpha=0.05)$.

- $\mathrm{Hg} \begin{aligned} & \text { Mercury at standard length } \\ & (\mathrm{a}, \mathrm{b} \text { and } d=400 \mathrm{~mm}, \mathrm{c}=700 \mathrm{~mm}, \mathrm{e}=600 \mathrm{~mm})\end{aligned}$

I Vertical bars represent confidence intervals $(\alpha<0.05)$ of average means.

Range of mean levels measured under natural conditions
for a standardized length. 
Fig. 3 (cont'd) Temporal evolution of mean total mercury (wet weight) levels and of Fulton's fish condition factor (K) for the major species in three reservoirs of the La Grande complex.

\section{c) Northern Pike}
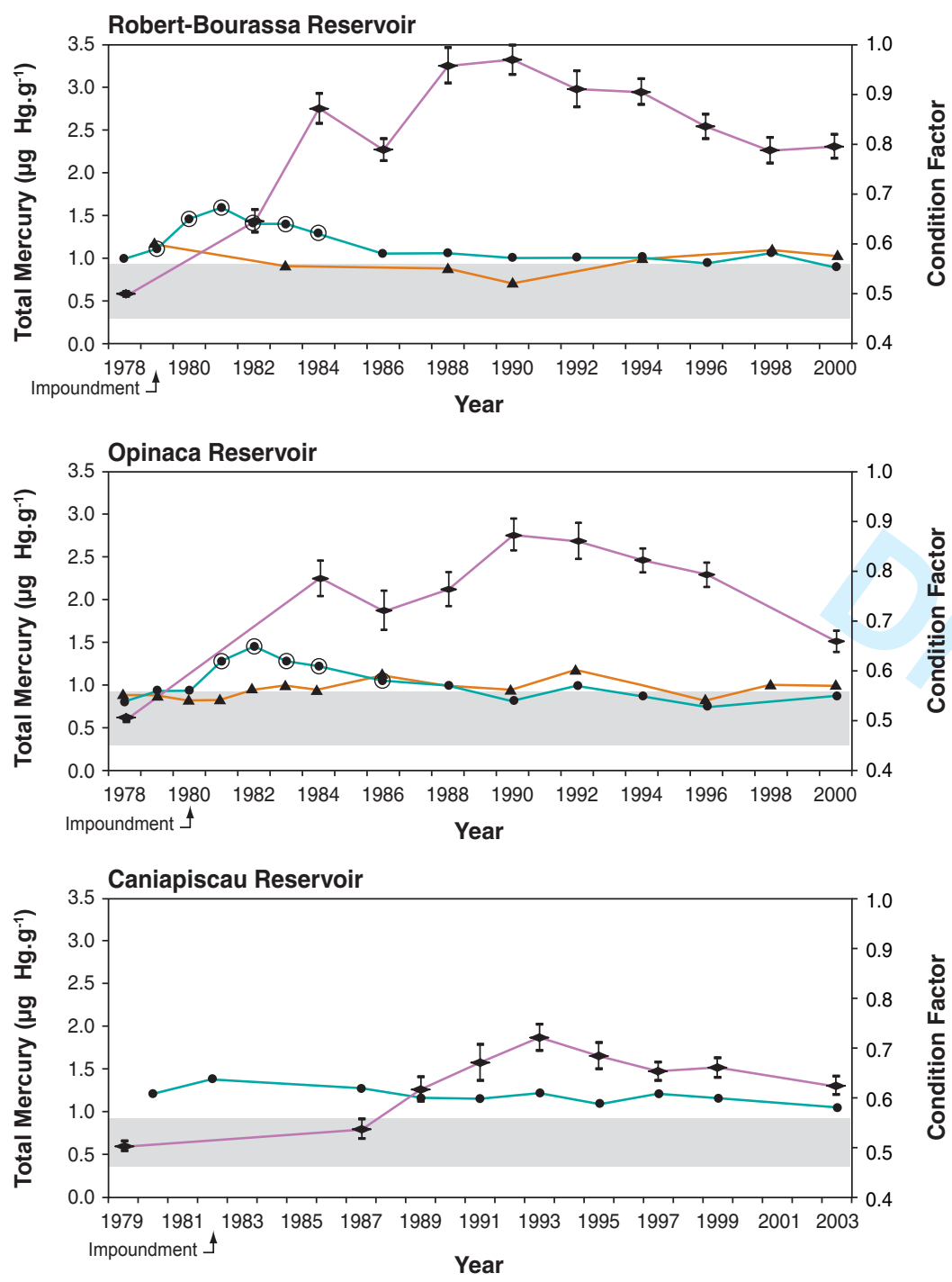

\section{d) Walleye}
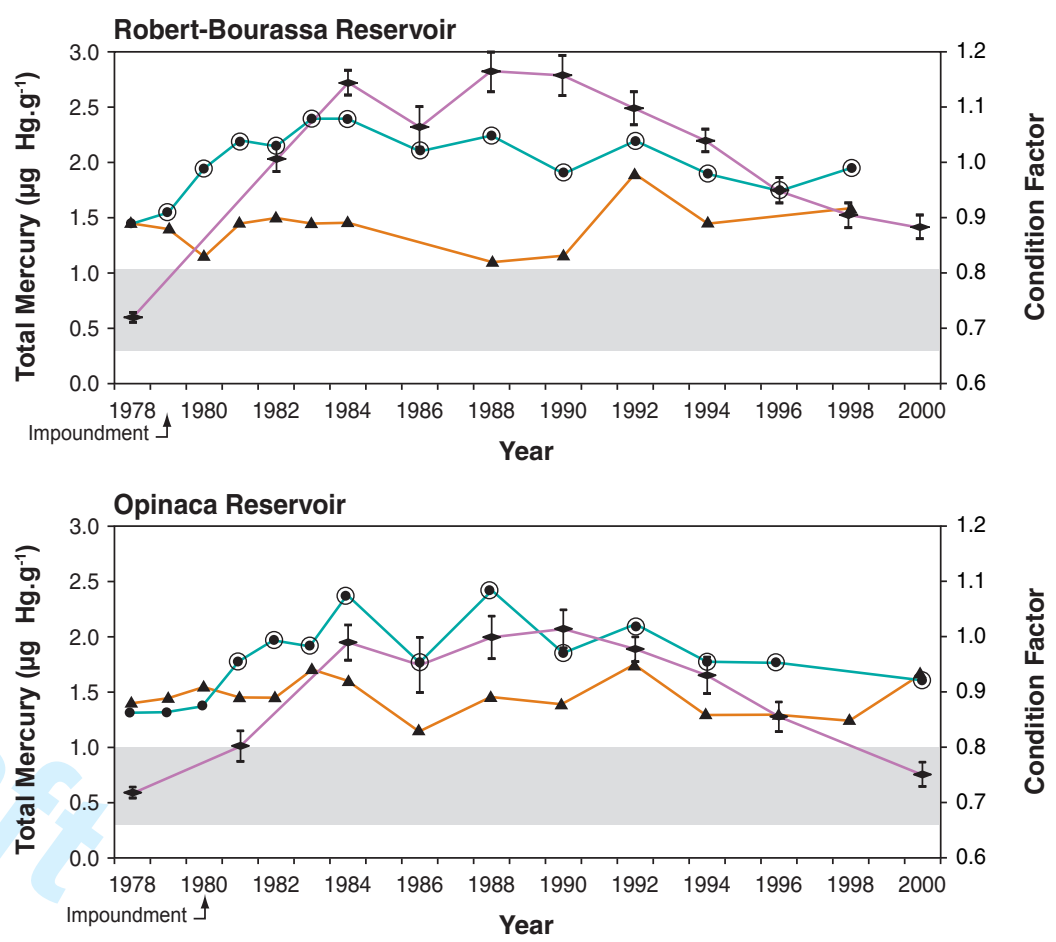

e) Lake Trout

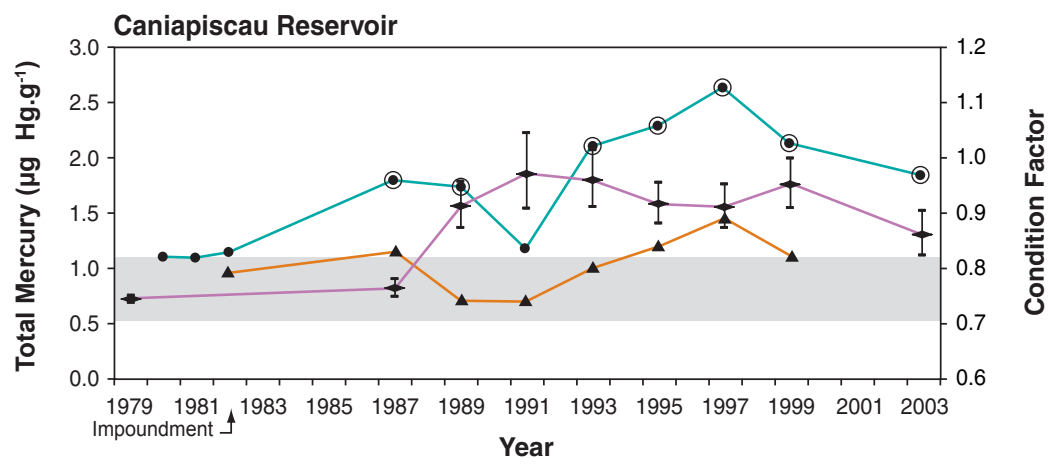

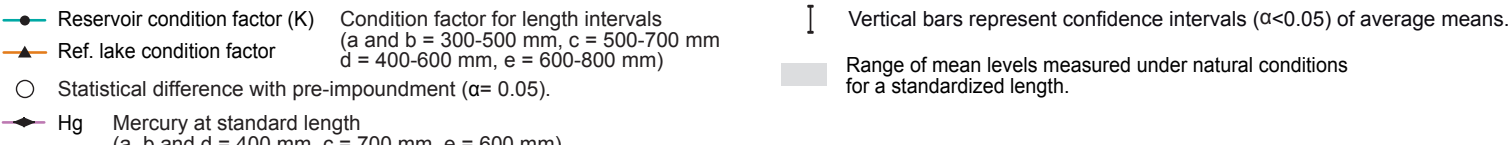

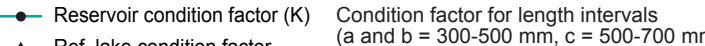
- Ref. lake condition factor $\quad(a$ and $b=300-500 \mathrm{~mm}, \mathrm{c}=500-700 \mathrm{~mm}$

O Statistical difference with pre-impoundment $(\alpha=0.05)$.

- $\mathrm{Hg}$ Mercury at standard length

I Vertical bars represent confidence intervals $(\alpha<0.05)$ of average means.

Range of mean levels measured under natural conditions
for a standardized length.

ttps://mc06.manuscriptcentral.com/cjfas-pubs 
Fig. 4 Annual von Bertalanffy growth curves for the major species in Robert-Bourassa Reservoir
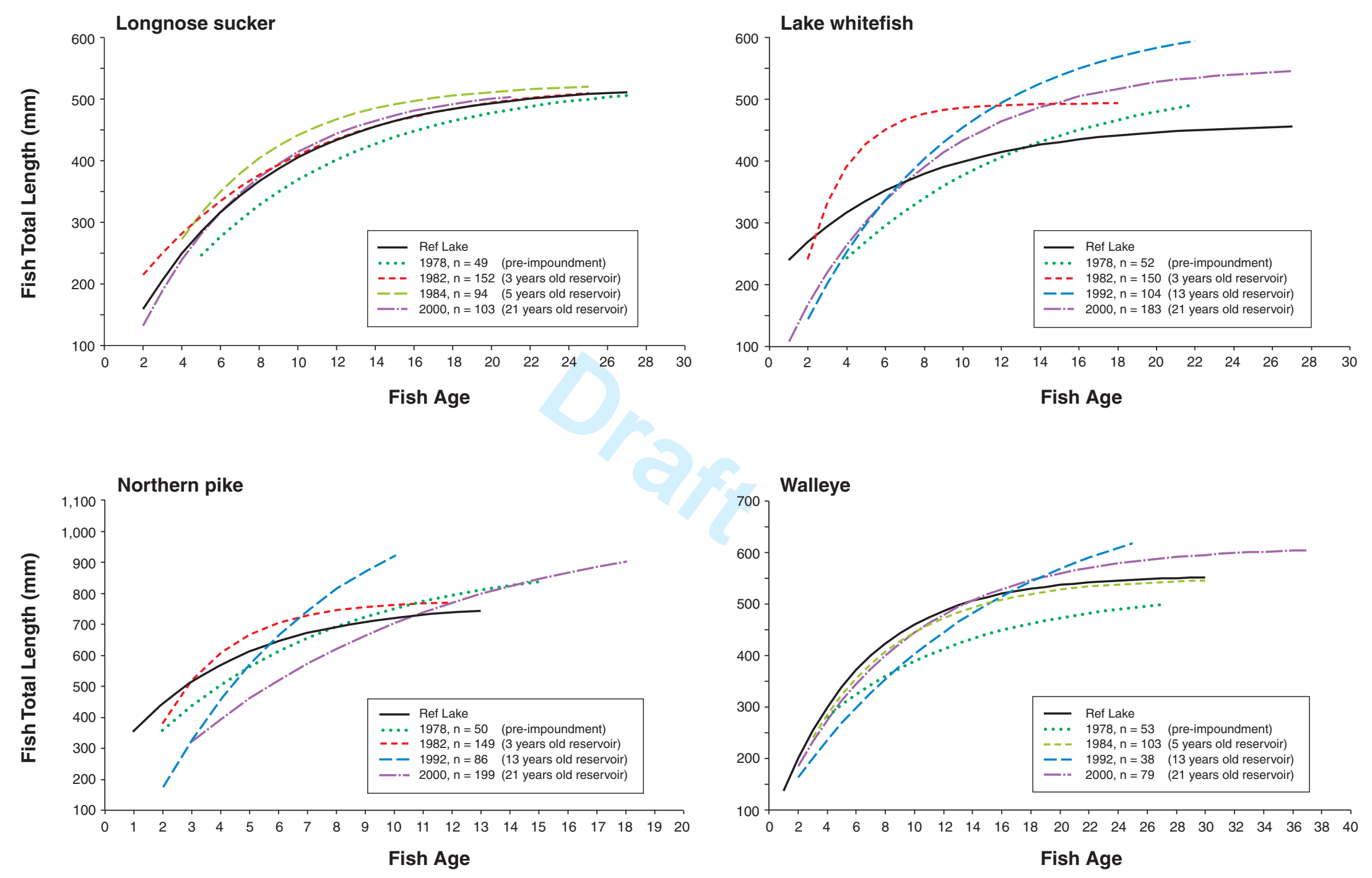
Fig. 5 Annual von Bertalanffy growth curves for the major species in Opinaca Reservoir
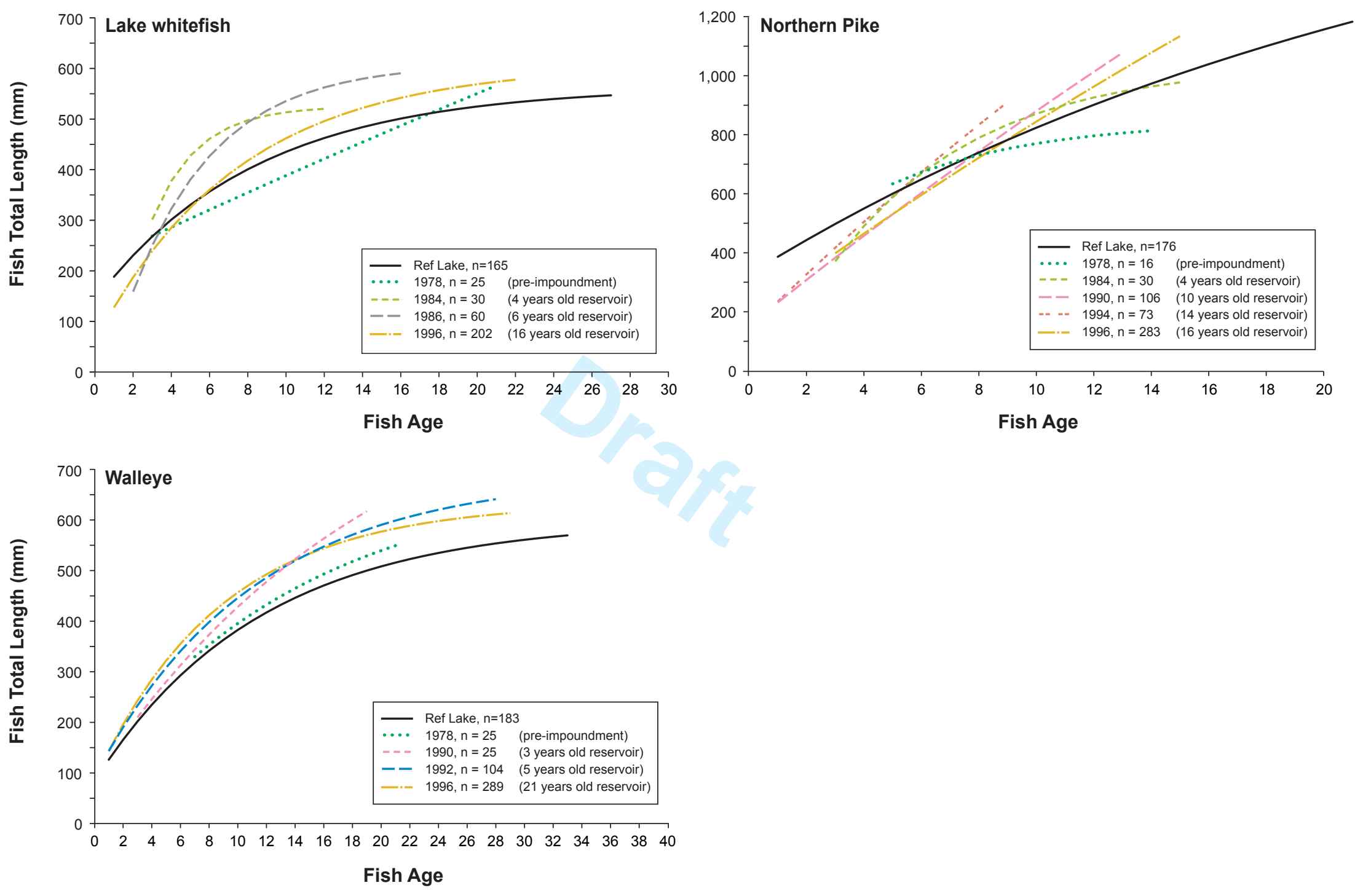
Fig. 6 Annual von Bertalanffy growth curves for the major species in Caniapiscau Reservoir
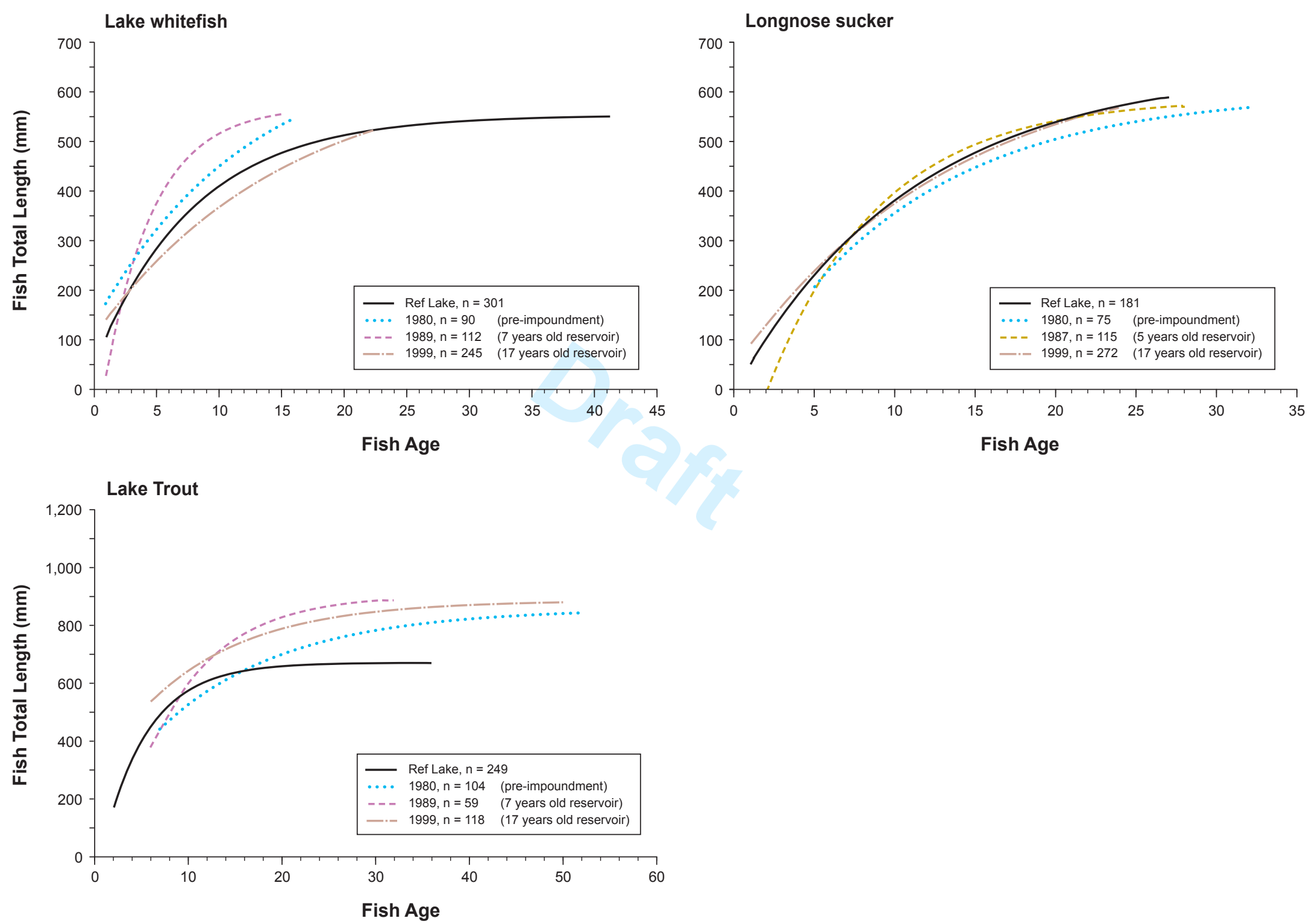